\title{
$1 \quad$ Variation in fuel structure of boreal fens
}

2 T. J. Schiks ${ }^{1,2}$, B. M. Wotton ${ }^{2,3 *}$, M. R. Turetsky ${ }^{1}$, B.W. Benscoter ${ }^{4}$

$3{ }^{1}$ Department of Integrative Biology, University of Guelph, Guelph, Ontario, N1G 2W1 Canada

$4 \quad{ }^{2}$ Faculty of Forestry, University of Toronto, Toronto, Ontario, Canada M5S 3B3

$5 \quad{ }^{3}$ Natural Resources Canada-Canadian Forest Service, Great Lakes Forestry Centre, Sault Ste. Marie,

6 Ontario, Canada P6A 2E5

$7 \quad{ }^{4}$ Department of Biological Sciences, Florida Atlantic University, Davie, Florida 33314 USA

8 * Corresponding author. E-mail: mike.wotton@utoronto.ca 


\section{Abstract.}

10 Wildfire frequency and severity in boreal peatlands can be limited by wet fuel conditions, but increases

11 in burn severity can occur when lower water table positions cause drying of fuels. Most studies on

12 northern peatland fires to date have focused on ombrotrophic bogs. Though minerotrophic fens are the 13 most common type of peatland in North America, the influence of fuel structure and loading on potential 14 fire behaviour in boreal fens is poorly understood. To investigate the potential for widespread flame 15 front propagation across boreal fens, we quantified the fuel components present in three generalized 16 boreal fen types (open, shrub, and treed fens) in northern Alberta, Canada. The loadings of aerial fuels, 17 tall shrubs, and downed woody debris varied significantly among fen types. Fuel loads tended to be 18 smallest in the open fens and largest in the treed fens. Open and shrub fens had larger loads of total 19 surface fuels relative to treed fens, with short-statured shrubs being the dominant contributor to surface 20 fuel load. Based on our observations of available fuel loads, each of the fen types may support moderate 21 to high intensity fire following long-term drying, which may consume not only some fraction of the 22 aboveground biomass but also provides a substantial downward pulse of energy to initiate smouldering 23 in the organic layer.

25 Keywords: peatlands, wildfire, fuel type, forest biomass, fuel load 


\section{Introduction}

Historically, boreal wildfire research has focused largely on upland forests, while peatlands have received relatively little attention despite covering approximately $12 \%\left(1.136\right.$ million $\left.\mathrm{km}^{2}\right)$ of Canada's land area (Tarnocai 2009). Boreal and subarctic peatlands represent a long-term net sink for atmospheric carbon (C) because net primary productivity and input of organic matter to soils exceeds soil C losses due to decomposition and disturbance such as combustion (Harden et al. 2000). Despite their function as a net $\mathrm{C}$ sink, these ecosystems are prone to losses of $\mathrm{C}$ along with mercury and trace gases via burning during wildfire. Smoke emissions associated with peat fires can pose significant hazards to air quality and human health (Flannigan et al. 2009; Rappold et al. 2011; Johnston et al. 2012).

The frequency and intensity of wildfire in the boreal region are important controls on $\mathrm{C}$ storage (Bond-Lamberty et al. 2007). Fires can be ignited within peatlands (Turetsky et al. 2004) or spread from adjacent upland areas (Zoltai et al. 1998). Wildfires burned an estimated $1470 \pm 59 \mathrm{~km}^{2}$ year $^{-1}$ of peatlands between 1980 and 1995 in continental western Canada (i.e., Manitoba, Saskatchewan, Alberta; Turetsky et al. 2002). Peatland fires can consume some portion of the aerial and understory fuel strata

41 (e.g., trees, shrubs, herbs); however, surface (nonvascular plants, litter) and ground fuels (thick layers of 42 duff, organic soils, root biomass) are more typically consumed through smouldering combustion that 43 dominate peat fires (Zoltai et al. 1998; Benscoter and Wieder 2003; Rein et al. 2008). In many 44 undisturbed peatlands, wet conditions that keep water tables near the peat surface limit wildfire 45 frequency and the potential for deep organic matter consumption (Turetsky et al. 2011). However, 46 projected warming is expected to cause drying as a result of increased evapotranspiration, despite 47 potential increases in precipitation in some boreal regions. This will lower water table positions in 48 peatlands and may increase the availability of peatland ground fuels for smouldering combustion 
49 (Waddington et al. 2012). Furthermore, smouldering combustion can be maintained at a higher moisture

50 content than flaming combustion, thus allowing deeper ground fuels in these ecosystems to burn under

51 conditions that may not support active flaming (Frandsen 1997).

The vulnerability of peatlands to burning under contemporary climate is still poorly understood

53 (Turetsky et al. 2015). Fire season duration, fire occurrence and annual area burned are predicted to

54 increase across northern forests as climate conditions become warmer and drier (Wotton and Flannigan

55 1993; Stocks et al. 1998; Flannigan et al. 2001, 2005; Wotton et al. 2010). While depth of burn in the

56 ground layer is typically thought to increase with the date of occurrence within the fire season, there was

57 no observed increase in late season burning in Alaskan peatlands, which was likely prevented by high

58 moisture content and surface permafrost present even during the late season burning period (Turetsky et

59 al. 2011). However, this trend may not apply to the large areas of peatland present south of the

60 discontinuous permafrost region. Particularly in these areas, a future warming trend is likely to result in

61 lower water tables and drier organic soils, potentially leading to deeper organic matter consumption

62 during burning and significant soil C losses (Turetsky et al. 2011). Because the vast majority of the

63 peatland $\mathrm{C}$ stocks reside belowground (only about $0.10 \mathrm{Pg} \mathrm{C}$ is aboveground biomass in continental

64 western Canada), this portion is of primary concern for C cycling (Vitt et al. 2000b). Under a scenario of

65 increasing wildfire activity, $\mathrm{C}$ emissions may very well exceed $\mathrm{C}$ uptake in these ecosystems, thus

66 diminishing the function of northern peatlands as a C sink (Wieder et al. 2009). system used extensively by fire management agencies across Canada, do not include fuel complex characterization that would adequately describe the available fuels within peatland ecosystems; the boreal spruce model (C-2) explicitly excludes "spruce-Sphagnum bogs" (Forestry Canada Fire Danger

71 Group 1992). The fire spread that may be exhibited in peatlands likely differs from that of uplands, 
72 because fire behaviour is sensitive to fuel load, arrangement, connectivity and flammability of the fuel

73 strata present. Continental peatlands of western Canada are typically forested. Ombrogenous bogs in

74 this region are dominated by black spruce (Picea mariana (Mill) BSP.). Geogenous fens, on the other

75 hand, vary more widely in canopy structure, and can be forested (either with black spruce or larch [Larix

76 laricina (Du Roi) K. Koch]), or can lack a continuous tree canopy (Vitt 2000a). These differences in

77 vegetation structure are partially attributed to differences in hydrology and minerotrophy. For example,

78 mean growing season water table positions typically range from $10 \mathrm{~cm}$ above to $40 \mathrm{~cm}$ below the peat

79 surface in fens, and from 40 to $60 \mathrm{~cm}$ below the peat surface in bogs (Vitt et al. 2000b). Together,

80 variation in vegetation structure and organic layer moisture content will dictate fire danger (Wotton

81 2009), as dry wooded peatlands are more prone to burning than open or shrub dominated peatlands

82 (Turetsky et al. 2002). Recently, Johnston et al. (2015) compared fuel loads and structure along a

83 chronosequence of Sphagnum-dominated bogs in northern Alberta to better understand successional

84 trends in fuel loading and structure over time. In general, they found that consistent surface fuel loads

85 and a lack of fuel strata gap (typically $<0.1 \mathrm{~m}$ ) between the surface and the crowns could support crown

86 fire initiation in all sites along their chronosequence. At $\sim 60$ years following fire, the canopy bulk

87 density of black spruce was sufficient to support active crown fire, and at $\sim 80$ years it could support

88 active crown fire on approximately $10-40 \%$ of days during a fire season. No studies to date have

89 considered fuel structuring in fens, despite the fact that fens constitute more than $60 \%$ of peatland area

90 in continental western Canada (Vitt et al. 2000a). In general, very little is known about the conditions

91 needed to support widespread flame front propagation in fen ecosystems.

92 The purpose of this study was to identify and quantify fuel components available to support

93 flame front spread through three fen types along a hydrological and vegetation gradient in northern

94 Alberta, Canada. These fen types (open/sedge fens, shrub fens, and treed fens) are representative of the 
95 cross-section of fens in continental Canada, reflecting the variation in the structure and type of fuel 96 available to support burning. A second goal was to develop allometric equations for peatland larch that 97 could be used, along with similar previously developed models for bog black spruce, to estimate overall 98 available aerial fuels in treed peatlands.

100 Methods

101 Study site

We identified eleven fen sites in northern Alberta to examine inter-site variability in fuel 103 structure, composition and load (Figure 1; Table 1). Sites were identified using wildfire maps from the 104 Canadian Large Fires Database and the Canadian National Fire Database (Natural Resources Canada; 105 available from http://cwfis.cfs.nrcan.gc.ca) and were confirmed with aerial photography and ground 106 reconnaissance. All sites were representative of the continental boreal, and vegetation communities in 107 several of these sites are described in more detail by Miller et al. (2015). Our sites are located in the 108 Central Mixedwood Natural Subregion of the Boreal forest (Natural Regions Committee 2006). Each 109 site was categorized into one of three general categories: treed fen, shrub fen, or open fen. Open sites 110 were those consisting primarily of sedges (primarily Carex spp.) with infrequent small bog birch. Shrub

111 sites were dominated by taller shrubs (primarily Betula pumila) with some graminoids and sparse larch 112 or spruce trees. Treed sites were dominated by larch and/or black spruce with a shrub understory (Figure 1132 ).

\section{$115 \quad$ Fuel load characterization}

116 Sampling of each site involved characterization of aerial and surface fuel components. Sampling 117 was performed at each site along a $100 \mathrm{~m}$ transect, with four $10 \mathrm{~m}$ x $10 \mathrm{~m}$ quadrats spaced evenly on 
118 alternating sides of the transect. The transect was established with a random starting point and bearing, 119 and a new bearing that was constrained to avoid sampling overlap was chosen at $50 \mathrm{~m}$ for the remainder 120 of the transect to minimize potential sampling bias resulting from prevailing orientation of dead and 121 down woody fuels. The focus of this study was to characterize fuels available to support combustion, but 122 was constrained to the fuel strata present above the ground fuel layer. We did not sample deeper peat 123 soils to reconstruct full peat profiles; however, we did measure peat thickness at the centre of each site 124 using a soil depth probe.

The fuel load from downed woody debris was estimated using the line intersect (or planar 126 intercept) method (Van Wagner 1968, 1982; Brown 1974) along the entire 100 m transect. Woody 127 pieces under $7 \mathrm{~cm}$ were measured with a "go-no-go" gauge and tallied for the following diameter size 128 classes: $<0.5,0.5-1.0,1.0-3.0,3.0-5.0$ and 5.0-7.0 $\mathrm{cm}($ McRae et al. 1979). For pieces $>7.0 \mathrm{~cm}$, each 129 diameter was recorded individually. Size class specific coefficients for the load calculation were taken 130 from Nalder et al. (1999) for black spruce from central Alberta. For pieces $>7 \mathrm{~cm}$ roundwood diameter, 131 we used methods described by Alexander et al. (2004) and specific gravity value of $0.427 \mathrm{~g} / \mathrm{cm}^{3} \mathrm{from}$ 132 Ter-Mikaelian et al. (2008). Surface fuels were destructively sampled using eleven $30 \mathrm{~cm}$ x $30 \mathrm{~cm}$ 133 quadrats spaced evenly along the $100 \mathrm{~m}$ transect. Fuels sampled were all graminoids, herbaceous plants, 134 lichen, litter, shrubs (bog birch and willow) and tree seedlings (black spruce and larch $<0.5 \mathrm{~m}$ tall); 135 horsetail was excluded. All surface fuels that were rooted within the sampling quadrat were collected 136 down to the surface of the moss layer, placed in paper bags and transported to Meanook Biological 137 Research Station (formerly University of Alberta) for processing.

138 Under some fuel descriptions, shrub fuels up to $2 \mathrm{~m}$ tall would be grouped generally with surface 139 fuels (Keane 2015). Recent fuel layer classifications from Australia (Gould et al. 2007; Hines et al. 140 2010) have used visually distinguishable layers that could be associated with differing fire behaviour. In 
141 these Australian classification systems, low shrubs would be considered 'near-surface' fuels (and thus in 142 our summaries we have included them with the surface fuels), and the observed tall shrubs $(>50 \mathrm{~cm})$ 143 would be described as 'elevated' fuel. We feel that grouping fuel layers as such creates a useful 144 distinction for elements of the fuel complex that can significantly alter fire behaviour. Stand structure parameters were inventoried within each $10 \mathrm{~m}$ x $10 \mathrm{~m}$ quadrat. All trees $>0.5 \mathrm{~m}$ 146 tall were recorded for: species, height $(\mathrm{cm})$, live crown-base height $(\mathrm{CBH}, \mathrm{cm})$, diameter-at-breast 147 height $(\mathrm{DBH}, \mathrm{cm})$ and basal diameter $(\mathrm{cm})$. Crown base height $(\mathrm{CBH})$ was measured from the moss 148 surface to the lowest continuous branches of the tree. Basal diameter was measured above any root 149 collar swelling to avoid a bias towards large stem diameters. Shrub fuels $>0.5 \mathrm{~m}$ tall (bog birch, willow) 150 were measured at the stem base to estimate biomass via foliage and stem allometric equations (Connolly 151 and Grigal 1983).

152 In the laboratory, surface fuels were sorted, allowed to air cure, then oven-dried in a low 153 humidity environment at 40 degrees Celsius to a constant mass. Dry weight was then recorded to the 154 nearest $0.01 \mathrm{~g}$. Within each site, fuels loads in each of the eleven $900 \mathrm{~cm}^{2}$ quadrats were averaged by 155 fuel category.

\section{Tree and canopy fuel load modelling}

The majority of trees in these fen types were either black spruce or larch. As allometric equations 159 for bog black spruce had recently been developed for this same area (Johnston et al. 2015), we focused 160 on destructive sampling of aboveground biomass in larch over the range of diameters observed in other 161 recent studies in our study area (e.g., Miller et al. 2015). In July and August of 2010, we destructively

162 harvested larch trees from fens within the general study area. Trees were sampled from three of the 163 treed sites listed in Table $1(\mathrm{~T} 1, \mathrm{~T} 2, \mathrm{~T} 5)$ as well as two additional fens (McLennan, AB: 55.8724, - 
164 116.9166; Cold Lake, AB: 55.2852, -111.3210). Stand DBH and height were used to determine the 165 range and distribution of larch sizes present at each site, and individuals were selected to obtain an 166 approximately equal distribution of size classes for the five sites collectively, as each stem diameter size 167 was not present at every site. Basal diameter, $\mathrm{DBH}$ and total height were recorded for each individual 168 harvested. Trees were cut at the ground moss surface and the entire tree was divided into sections with a 169 chainsaw and branches were removed from the boles. All biomass from this process was placed in paper 170 bags and stored at the Meanook Biological Station until they were shipped to the University of Guelph 171 in September 2010. Biomass was quantified separately for each tree and sorted into the following 172 categories: branches, needles, stem (with bark attached) and cones. The branches were further divided 173 into size classes I-III, equating to roundwood diameters: $<0.5,0.5-0.99,1.0-2.99 \mathrm{~cm}$, respectively 174 (McRae et al. 1979). Branchwood did not exceed a diameter of $3.0 \mathrm{~cm}$. Samples were oven-dried at 95 175 degrees Celsius to a constant mass; the dry weight was recorded to the nearest $0.01 \mathrm{~g}$. The total biomass 176 for each individual tree was determined by summing the weighed biomass of all categories. Available 177 branchwood fuel was determined by summing the weight of branch size classes I and II (i.e., $<1.0 \mathrm{~cm}$ 178 diameter) for an individual tree.

Two available fuel load equations were developed for larch representing the two components of 180 the crown that would consumed during the passage of a flaming front and contribute to fireline intensity, 181 foliage and branchwood $<1 \mathrm{~cm}$ diameter. We created allometric equations to model oven-dried tree 182 biomass components as a function of tree diameter (e.g., Pastor et al. 1984; Crow and Schlaegel 1988; 183 Ter-Mikaelian and Korzukhin 1997). Graphical inspection of the relationship between tree biomass and 184 diameter (DBH or basal diameter) showed that these data did exhibit the typical power function form 185 and increasing variance with increasing value seen in previous studies and thus should be log- 
186 transformed. Linear regression was used on the transformed data to determine a line of best fit, using the 187 form:

$$
\ln (Y)=\ln (a)+b \ln (D)
$$

where $Y$ is the mass of the biomass component $(\mathrm{kg})$ and $D$ is the tree diameter, $\mathrm{DBH}$ or basal diameter

191 (cm). Two sets of diameter-based models were created to accommodate differing user inputs; DBH is a 192 common stand characteristic, although it would exclude smaller trees $(<1.4 \mathrm{~m}$ tall $)$ that contribute to 193 total aerial fuel loads.

Canopy fuel load (CFL) and canopy bulk density (CBD) were calculated using the allometric equations and stand inventory data (following Alexander et al. 2004). Available branchwood $(<1 \mathrm{~cm})$ and foliage biomass were estimated for each individual tree surveyed in the four $10 \mathrm{~m}$ by $10 \mathrm{~m}$ quadrats.

Canopy fuel load $\left(\mathrm{kg} / \mathrm{m}^{2}\right)$ was the sum of available branchwood and foliage for all trees, divided by the 198 quadrat sampling area $\left(100 \mathrm{~m}^{2}\right)$. Canopy bulk density $\left(\mathrm{kg} / \mathrm{m}^{3}\right)$ was calculated by dividing canopy fuel 199 load by mean crown length (m) (i.e. tree height minus live crown-base height).

\section{Statistical analysis} among three fuel types: treed $(n=16)$, shrub $(n=12)$, open $(n=10)$. Fuel load values were standardized using the Hellinger-transformation (Legendre and Gallagher 2001). Each plot consisted of estimates of component fuel loads based on the $10 \mathrm{~m}$ x $10 \mathrm{~m}$ tree plot, the mean load of two surface fuel quadrats, and a $25 \mathrm{~m}$ segment of the line transect. Analyses were performed with R software (v3.1.2; R Core 207 Team, 2015) using the 'vegan' and 'BiodiversityR' packages. 
Additionally, we compared mean fuel load values across fuel types. The datasets failed a

209 normality test (Shapiro-Wilk test, Q-Q plot), and therefore the non-parametric Kruskal-Wallis One Way

210 ANOVA on Ranks ( $\alpha=0.05)$ was applied to test for differences in loading of each fuel component

211 within each fuel type and across the three fuel types; any significant differences were further

212 investigated with non-parametric post-hoc testing using the Wilcoxon rank-sum test. Analyses were

213 performed using R software (v3.1.2; R Core Team, 2015).

\section{Potential fire behaviour}

216 As a first approximation of potential fire behaviour in the three fen fuel types, we estimated fire 217 intensity based on the classic equation presented by Byram (1959). Fireline intensity, $I(\mathrm{~kW} / \mathrm{m})$ was 218 estimated as:

$$
I=H w r
$$

221 where $H$ is the fuel low heat of combustion $(18000 \mathrm{~kJ} / \mathrm{kg}), w$ is the weight of the fuel layer consumed 222 per unit area $\left(\mathrm{kg} / \mathrm{m}^{2}\right)$, and $r$ is the rate of spread $(\mathrm{m} / \mathrm{s})$. While there are a number of fire line 223 intensity/flame length relationships in the literature, for the sake of consistency and the relative 224 comparisons made herein, flame length, $L(\mathrm{~m})$, was also estimated by a relationship first developed by 225 Byram (1959) as:

226

$$
L=0.0775 I^{0.46}
$$


228 where $I$ is fireline intensity in $\mathrm{kW} / \mathrm{m}$ (Alexander 1982). For the purpose of this discussion, $25 \mathrm{~m} / \mathrm{min}$ rate 229 of spread was assumed for comparison of fireline intensities between fen fuel types.

$231 \quad$ Results

Fen fuel loading respectively). Shrub and treed fens had similar mean peat depths, while open fens had shallower peat on average (Table 1). Site-level fuel loading is summarized in the Appendix (Table A1-A5).

Mean total fuel load varied across the fen types, and were larger in the treed fen sites $(0.982 \pm$ $\left.0.098 \mathrm{~kg} / \mathrm{m}^{2}\right)$ than in the open or shrub sites $\left(0.482 \pm 0.045 \mathrm{~kg} / \mathrm{m}^{2}\right.$ and $0.686 \pm 0.073 \mathrm{~kg} / \mathrm{m}^{2}$, average (Table 1). Site-level fuel loading is summaized in the Appendix (Table Al-A5).

Total surface fuel load was overall consistent across the three fen types $(p>0.05)$, with similar amounts of herbaceous, litter and graminoids in each of the fen types (Table 2). The dominant contribution to total surface load came from the short-statured shrubs $(<50 \mathrm{~cm})$, consisting primarily of short-statured bog birch, which comprised on average $66 \%$ of the total surface fuel load across all sites (range $=30-84 \%)$. The contribution of tall shrub fuels $(>50 \mathrm{~cm})$ varied across fen types $(p<0.001$; Table 2). As expected, tall shrubs were mostly absent from the open sites. Shrub fen sites were dominated by bog birch and a minor component of willow. The treed sites tended to have both willow and bog birch, and alder was also present, though tall shrubs were completely absent from one of the treed sites (site 'T3').

Downed woody debris (DWD) on the surface varied among the fen types $(p<0.001)$. Not surprisingly, DWD fuel loads were extremely low in the open sites and were highest in the treed sites (Table 2). In the treed fens, assuming that only the size class I and II fuels $(<0.5$ and $0.5-1.0 \mathrm{~cm}$, respectively) would be available to contribute to flaming combustion, average DWD fuel loads $(0.021 \pm$ $0.005 \mathrm{~kg} / \mathrm{m}^{2}$ ) were a small fraction of the surface litter load (range: 13-64\%) or of the total surface fuel 
251 load (range: 4-18\%). Thus, the contribution of down and dead woody material to flame front intensity is 252 marginal. Coarse woody debris $(>7 \mathrm{~cm})$ was also present in four of the five treed sites, but was absent 253 from the open and shrub sites. spruce and larch composing the tree canopy (Table 3). The distribution of basal diameter from each of the treed and shrub fen sites (Figure 3) show large site-to-site variation in the proportion of black spruce and larch. Allometric equations for larch (described below) and black spruce bog (Johnston et al. 2015) were used with the tree density survey information to estimate overall average canopy fuel load and bulk density across sites (Table 4). Canopy bulk density in the treed fen sites ranged from 0.140 to 0.407 $\mathrm{kg} / \mathrm{m}^{3}$, which was similar to black-spruce dominated bogs that ranged from 0.166 to $0.543 \mathrm{~kg} / \mathrm{m}^{3}$ for sites that were approximately 30 to 110 years following fire (Johnston et al. 2015). Fireline intensity was modeled using the available component of fuels for each fen type, and the results are summarized in Table 5.

Principal component analysis identified two primary axes that together explained $\sim 54 \%$ of the variability of the fuel load composition (first axis explained 36\% of variation; the second axis explained an additional $18 \%$ of variation). A permuted multivariate analysis of variance (Adonis R package; 1000 permutations) suggested that the 'fen fuel type' classification was significant $(p<0.001)$ and explained $35 \%$ of variability in fuel loads. Sites clustered into these three fen categories along Axis 1, which primarily separated open from treed sites, while Axis 2 primarily separated treed from shrub fens (Figure 4). The abundance of surface shrubs $(<0.5 \mathrm{~m}$ tall) was correlated with the open fen sites, whereas the abundance of larch fuels was correlated with the treed fen sites (Figure 4).

\section{Larch allometric equations}


Biomass measurements from 47 trees sampled across several fens were combined to generate

275 allometric equations for larch (Table 4). These trees ranged in basal diameter from 1.0 to $14.7 \mathrm{~cm}, \mathrm{DBH}$

276 ranged from 0.3 to $11.5 \mathrm{~cm}$, and total height ranged from $0.6 \mathrm{~m}$ to $8.5 \mathrm{~m}$. Overall, stem weight was

277 found to be the greatest contributor to total biomass for every individual, followed by branches with a 278 diameter of $<0.5 \mathrm{~cm}$ and then foliage. Models for total aboveground, stem (with bark), foliage, and 279 branchwood (total, $<0.5 \mathrm{~cm},<1.0 \mathrm{~cm}$ ) biomass were developed individually using Equation 1. Of all the 280 measured tree attributes, diameter was the single strongest predictor of biomass; basal diameter was a 281 slightly stronger predictor of total biomass than DBH $\left(r^{2}=0.984\right.$ and $r^{2}=0.947$, respectively); however 282 we developed separate models for both basal diameter and DBH because some studies, and many forest 283 inventory methods, report only DBH. The power law model form (Equation 1) represented the best fit 284 (Figure 5), with $\mathrm{r}^{2}$ values exceeding 0.95. Variance in residuals across the range of diameters was 285 relatively constant and did not exhibit any strong trends. Tree height was an additional significant 286 predictor in a forward selection multiple regression model form but offered little meaningful 287 improvement in predictive power. For example, once the effect of basal diameter was accounted for, the 288 partial variance explained in total tree biomass due to height was $\mathrm{r}^{2}=0.006(p<0.0001)$.

\section{Discussion}

\section{$291 \quad$ Fen fuel loading} strata in black spruce bogs to estimate crown fire sustainability. Results from that study suggested that while torching would likely initiate at any site along their bog chronosequence, active crown fire would only likely be supported when an adequate canopy bulk density was achieved within the stand, around 
29760 years since last fire (Johnston et al. 2015). The objective of our study was to characterize trends in 298 fuel loading in boreal fens, given that fens are much more abundant on the landscape relative to bogs. 299 Our results indicate that a simple classification of fens into open, shrub, and treed fens explains a 300 significant amount of variation in fuel loading. For example, aerial fuels available to flaming 301 combustion, tall shrub density, and downed woody debris all varied among fen types, and tended to be 302 smaller in the open fens and largest in the treed fens (Table 2 and 3). On the other hand, total surface 303 fuel load was relatively constant across the fen types, as were the density/abundance of short statured 304 shrubs (<50 cm tall), which was the largest contributor to overall surface loads.

305 For some fuel components, our results in boreal fens compare reasonably well to those reported 306 in the boreal forested-bog fuel type (Johnston et al. 2015) and to other upland forest types. For example, 307 our mean estimate of the total surface fuel component in fens $\left(0.370 \pm 0.044 \mathrm{~kg} / \mathrm{m}^{2}\right)$ is similar to those 308 reported for bogs $\left(0.396 \pm 0.027 \mathrm{~kg} / \mathrm{m}^{2}\right.$, Johnston et al. 2015), but lower than for coniferous/deciduous 309 mixed upland forests $\left(0.88 \mathrm{~kg} / \mathrm{m}^{2}\right.$, Hely et al. $\left.2000 \mathrm{~b}\right)$, and lodgepole pine-white spruce upland forests $310\left(0.36-0.77 \mathrm{~kg} / \mathrm{m}^{2}\right.$, Kiil et al. 1968). However, when only cured litter and ground lichens are considered 311 (ignoring live, green and consequently very moist fuel on the surface and near surface), the mean fuel 312 load across the fen types $\left(0.075 \pm 0.007 \mathrm{~kg} / \mathrm{m}^{2}\right)$ was smaller than what has been reported for black313 spruce bogs $\left(0.186 \pm 0.023 \mathrm{~kg} / \mathrm{m}^{2}\right.$, Johnston et al. 2015) and upland fuel types $\left(0.24-0.32 \mathrm{~kg} / \mathrm{m}^{2}, \mathrm{Kiil}\right.$ et 314 al. $1968 ; 0.44 \mathrm{~kg} / \mathrm{m}^{2}$, Hely et al. 2000b). This is an indication that fire in these sites would be most 315 sustainable when this annual vegetation is in its cured state in the spring or late fall, or during a period of 316 extended drought and low surface moisture.

317 The amount of dead and down woody material observed on the surface in the forested fens 318 (Table 2) is much lower than what has been observed in upland stands (e.g., $2.5 \mathrm{~kg} / \mathrm{m}^{2}$, Stocks $1987 ; 2.0$ $319 \mathrm{~kg} / \mathrm{m}^{2}$ Stocks $1989 ; 4.5 \mathrm{~kg} / \mathrm{m}^{2}$, Hely et al. 2000a) but is similar to estimates from the northern boreal 
320 spruce lichen woodland fuel type $\left(0.38 \mathrm{~kg} / \mathrm{m}^{2}\right.$, Alexander et al. 1991$)$, which is associated with low stem 321 density. It seems likely that the smaller values of woody fuel loads in the boreal fens is because mosses 322 grow quickly in these ecosystems and overtake and bury any downed woody biomass (Loisel et al. 323 2012). Downed woody debris loads in forested bogs in the same general study area were highly 324 variable, ranging from virtually nothing to high values associated with a fresh deadfall (Johnston et al. 325 2015), but in general tended to be larger $\left(1.470 \mathrm{~kg} / \mathrm{m}^{2}\right)$ than what was observed in our study of boreal 326 fens. Generally, only small diameter downed woody debris is expected to contribute to flaming 327 combustion (Stocks et al. 2004); however, large dead woody fuels, and especially those that are buried 328 or intermixed with the peat layer, can hold smouldering fire for extended periods of time (Brown et al. 329 2003).

To support investigations of canopy fuel dynamics, tree biomass equations have been established 332 Lambert et al. 2005; Case and Hall 2008), and there are a number of algorithms for upland boreal tree 333 species. Relative to equations for upland forests, tree biomass algorithms for peatlands are relatively 334 rare. Site conditions, in particular nutrient status and hydraulic regime, differ significantly between 335 peatlands and uplands and result in characteristic differences in tree species' growth and stature, 336 emphasizing the need for peatland-specific equations. The few published equations of tree allometry in 337 peatlands have tended to focus on black spruce (Wieder et al. 2009; Johnston et al. 2015). Szumigalski 338 and Bayley (1996) report an allometric relationship for larch; however, the equation was developed for 339 larch $<1.9 \mathrm{~m}$ tall and was based on a small sample size $(n=6)$. We compared published allometric 340 equations from the literature with the models developed as part of this study (Figure 5). The 341 relationships reported in Bond-Lamberty et al. (2002) consistently under-predicted tree biomass relative 342 to our destructive measurements (Figure 5). We also compared our larch biomass equations with those 
343 developed by Johnston et al. (2015) for bog black spruce (Figure 5). We found that, for a given 344 diameter, larch sampled in our study have more available branchwood and less foliage than black spruce 345 (Figure 5). Larch and black spruce may be contributing to aerial fuel loading differently, and this is an 346 important consideration given that these species vary in percent composition and stem density across 347 treed fens. We suggest that the equations for larch developed as part of this study (Table 4) together with 348 the bog spruce equations presented in Johnston et al. (2015) will enhance the ability to characterize 349 aboveground biomass and fuel loads in forested peatlands of boreal Canada.

\section{Potential fire behaviour}

Fuels loads were assessed in terms of their availability to support combustion and influence wildfire behavior. In the open and shrub fuel types, there was not enough available canopy biomass to necessary to achieve active crown fire while Johnson (1992) suggested a minimum of $0.05 \mathrm{~kg} / \mathrm{m}^{3}$. However, our estimates of surface and elevated fuel loads are large enough to support relatively high intensity surface fire based on estimated fireline intensity (Eqn 2; Table 5). In the open fens, if the full surface load were available for combustion in the spring before considerable green up of live vegetation, we estimate that $0.426 \mathrm{~kg} / \mathrm{m}^{2}$ could be consumed. A fire spreading at $25 \mathrm{~m} / \mathrm{min}$ through the open fuel type would produce a fire-line intensity of $\sim 3200 \mathrm{~kW} / \mathrm{m}$, which would represent a moderate to high

361 intensity fire (Table 5). However, in their green state, grasses typically do not readily support the spread 362 of flame (Cheney et al. 1998, Cruz et al. 2015), given that the presence of very moist live vegetation acts 363 as a large energy sink. If graminoids, herbs and shrubs are removed from the surface fuel complex as 364 contributors to fire-line intensity, then the fuel load that remains (litter plus lichen) and consequently the 365 potential intensity of combustion both drop significantly $\left(0.05 \mathrm{~kg} / \mathrm{m}^{2}\right.$ and $375 \mathrm{~kW} / \mathrm{m}$, respectively). 
366 Given the presence of green vegetation in this open fen fuel complex, it is doubtful a fire could 367 propagate at this intensity (Cruz et al. 2015). However, the presence of the low shrub layer complicates 368 the projection of summer-time fire behaviour. If moisture levels in the live vegetation are low enough $369(<100 \% \mathrm{GMC})$, then propagation may be possible in areas with low densities of graminoids and other 370 green (live) vegetation. While some grassland spread models have been found to work well in 371 grasslands outside of Australia (Cheney et al. 1998, Kidnie and Wotton 2015), their predictive ability in this open fen type may be questionable and should be subject to further study.

The shrub fen sites, where fuel was vertically continuous from the ground up to heights of around 1-1.5 m, would likely evolve higher intensity fires and longer flames than the open sites. Trees were not present in sufficient quantity to support crown fire (apart from simple torching) and thus fire spread in this type would be best characterized as surface fire. If the surface fuels, size class 1 and 2 of the down and dead fuels, and fuels in the elevated layer (i.e., tall shrub branch and foliage) were completely available for combustion $\left(0.624 \mathrm{~kg} / \mathrm{m}^{2}\right)$, the resultant fire (spreading again at $25 \mathrm{~m} / \mathrm{min}$ ) would produce a fire-line intensity of $\sim 4700 \mathrm{~kW} / \mathrm{m}$. Tall shrub bulk densities observed in the shrub fen fuel type $\left(\sim 0.15 \mathrm{~kg} / \mathrm{m}^{3}\right)$ are on the low end of shrub fuels studied in other parts of the world $(0.1-6.1$ $\mathrm{kg} / \mathrm{m}^{3}$, Anderson et al. 2015). It is likely the shrub fuel complex within fen systems is moister overall than the mainly dry climate shrublands that dominated the Anderson et al. (2015) study; however their model might be useful for providing an upper range of potential spread rate.

Because the likelihood of canopy torching and crown fire occurrence increases with decreasing crown base height (Van Wagner 1977), we expect that the treed peatlands in this study would be prone to torching due to the very short crown base heights observed (Table 3). Van Wagner's (1977) model, which is used worldwide, suggests the critical intensity for the ignition of black spruce canopy given an average $\mathrm{CBH}$ of $0.8 \mathrm{~m}$ and foliar moisture content at $100 \%$ would be $120 \mathrm{~kW} / \mathrm{m}$, which represents a low 
389 intensity surface fire. Thus, if flaming propagation were possible, we expect that most of the black 390 spruce in forested fens would experience torching. This torching would likely cause tree mortality where 391 it occurred.

Van Wagner (1977) also established a widely used criterion for a minimum sustained crown fire spread rate in a conifer stand. While the rate of spread of active crowning threshold was used by Johnston et al. (2015) to discuss the increasing potential for sustainable crown fire and subsequent potential for widespread organic consumption in black spruce bogs, the species mix in treed fens makes these inferences more difficult. In most of our treed fen sites, the canopy was a mix of both black spruce and larch. Annual foliage in larch contains much more moisture than older hardened off pine or spruce foliage. Once established in late spring, the high moisture content in larch foliage should have more of a moderating role in combustion. Conversely, larch needles senesce and dry out in early autumn, though they remain attached to the branches for some time. That senesced component of aerial fuels, coupled 401 with curing surface fuels, may very well reinforce late-season vulnerability to burning. By late autumn 402 the larch needles are abscised and contribute the surface fuel strata. type (M-1/M-2), which is a blend of black spruce and aspen (a broadleaf deciduous) and in which deciduous moderates spread rate through the spruce forest. While the black spruce component of canopy 406 fuel load in the treed fen sites is lower than observed in upland stands (e.g., Alexander et al. 2004), the 407 mean canopy bulk density of black spruce in our sites $\left(0.168 \pm 0.040 \mathrm{~kg} / \mathrm{m}^{3}\right)$ is similar to those in 408 uplands, due to the short crown length in fens. Thus, in the absence of larch, black spruce would be able 409 to sustain active crown fire spread for values of spread rate greater than about $22 \mathrm{~m} / \mathrm{min}$ (an easily 410 attainable fire spread rate with a moderate wind). A full crown fire in this fuel type in spring, spreading 411 at $25 \mathrm{~m} / \mathrm{min}$ would produce a fireline intensity of $\sim 5500 \mathrm{~kW} / \mathrm{m}$ (based on total fuel consumed of 0.734 
$412 \mathrm{~kg} / \mathrm{m}^{2}$ assuming the larch needles are absent from the canopy and larch branchwood is a passive 413 contributor that does not add to fire front energy). This would represent a high intensity fire that would 414 be able to ignite smouldering combustion in the surface peat layers, depending on type and most 415 importantly current moisture status (Thompson et al. 2015). However, during the summer, the 416 moderating effect of moist larch foliage would reduce spread rates and consequently intensity.

417 Though peatland burning is generally dominated by smouldering combustion, the flaming and 418 smouldering processes are linked, and fuels can transition from flaming to smouldering (i.e., residual 419 smouldering combustion) and vice versa (Rein 2013). Thompson et al. (2015) showed that energy output 420 from flame front propagation through surface and aerial fuels can ignite surface layers depending on the 421 energy from the flame front itself, which depends on spread rate, fireline intensity, and the moisture in 422 the surface organic layer. Thus with higher fuel loads and associated higher potential fire intensities, 423 treed and shrub fen fuel types may be more prone to the ignition of the ground fuel layer, though deep 424 burning would be moderated by moisture and oxygen. In terms of ground layer consumption across this 425 range of fuel types, seasonal trends in the water table influences moisture content in organic layers, 426 which is an important control of fuel consumption in peatland ground fuels (Benscoter et al. 2011; 427 Huang et al. 2015). Waddington et al. (2012) linked the drying of surface moss in peatlands at several 428 sites across Canada to water table depth and correlated this with the Canadian Drought Code of the 429 Canadian Fire Weather Index System (Van Wagner 1987). Knowledge about the availability of fuels 430 should enhance our assessments of the vulnerability of peatlands to burning, and might inform fire 431 operations in assessing prolonged smouldering. 
This is the first study to characterize the fuel environment for different types of boreal fens. We

435 found that boreal fens tend to have somewhat similar amounts of surface and aerial fuel loads relative to 436 boreal bogs; however, the deciduous nature of the larch present in treed fens is an important 437 consideration for seasonal fuel load dynamics, fuel moisture and availability, and the types of fire that 438 can be supported. Relative to uplands, both fens and bogs had smaller loads of downed woody debris. 439 Based on the total available fuel loads, we conclude that boreal fens are susceptible to high intensity 440 fires during certain periods of the fire season, such as early in the fire season when surface fuels have 441 cured but new foliage has not emerged, or late in the fire season when the larch needle component has 442 senesced and dropped from the aerial fuel strata to the surface.

\section{Acknowledgements}

445 Funding for this project was provided by a Natural Sciences and Engineering Research Council 446 of Canada (NSERC) Strategic Grant to M.R.T., J.M. Waddington, and B.M.W. The authors also 447 acknowledge the efforts of the PeatFire field crews from 2010 and 2012, in particular Abra Martin and 448 Carolyn Gibson. We thank J.L.W. Ruppert for providing statistical advice. Dan C. Johnston (OMNRF) 449 and Dan K. Thompson (Northern Forestry Centre-NRCAN) provided advice on field sampling and fens. 


\section{References}

Agee, J.K. 1996. The influence of forest structure on fire behavior. In: Proceedings of the $17^{\text {th }}$ annual forest vegetation management conference, Redding, California, USA. January 16-18. pp52-68.

Alexander, M. E. 1982. Calculating and interpreting forest fire intensities. Can. J. Bot. 60 (4): 349-357.

Alexander, M.E., Stocks, B.J., and Lawson, B.D. 1991. Fire behavior in black spruce-lichen woodland: the Porter Lake project. For. Can. Inf. Rep. NOR-X-310. Northern Forestry Centre, Edmonton, Alberta, Canada.

Alexander, M.E., Stefner, C.N., Mason, J.A., Stocks, B.J., Hartley, G.R., Maffey, M.E., Wotton, B.M., Taylor, S.W., Lavoie, N., and Dalrymple, G.N. 2004. Characterizing the Jack Pine - Black Spruce fuel complex of the International Crown Fire Modelling Experiment (ICFME). Can. For. Serv. Rep. NOR-X 393.

Anderson, W.R., Cruz, M.G., Fernandes, P.M., McCaw, L., Vega, J.A., Bradstock, R.A., Fogarty, L., Gould, J., McCarthy, G., Marsden-Smedley, J., Matthews, S., Mattingley, G., Pearce, H.G., and van Wilgen, B.W. 2015. A generic, empirical-based model for predicting rate of fire spread in shrublands. Int. J. Wildland Fire 24: 443-460. doi: 10.1071/WF14130.

Benscoter, B.W., and Wieder, R.K. 2003. Variability in organic matter lost by combustion in a boreal bog during the 2001 Chisholm fire. Can. J. For. Res. 33: 2509-2513. doi: 10.1139/x03-162. 
Benscoter, B.W., Thompson, D.K., Waddington, J.M., Flannigan, M.D., Wotton, B.M., de Groot, W.J., and Turetsky, M.R. 2011. Interactive effects of vegetation, soil moisture and bulk density on depth of burning of thick organic soils. Int. J. Wildland Fire 20: 418-429. doi: 10.1071/WF08183.

Bond-Lamberty, B., Wang, C., and Gower, S. 2002. Aboveground and belowground biomass and sapwood area allometric equations for six boreal tree species of northern Manitoba. Can. J. For. Res. 32: 1441-1450. doi: 10.1139/x02-063.

Bond-Lamberty, B., Peckham, S.D., Ahl, D.E., and Gower, S.T. 2007. Fire as the dominant driver of central Canadian boreal forest carbon balance. Nature 450 (7166): 89-92. doi:10.1038/nature06272

Brown, J.K. 1974. Handbook for inventorying downed woody material. USDA Forest Service General Technical Report No. INT-16.

Brown, J.K., Reinhardt, E.D., and Kramer, K.A. 2003. Coarse woody debris: managing benefits and fire hazard in the recovering forest. UDSA Forest Service General Technical Report RMRS-GTR-105.

Byram, G.M. 1959. Combustion of forest fuels. In: Davis, K.P. (editor). Forest fire: control and use. New York, NY: McGraw-Hill. 
Case, B., and Hall, R. 2008. Assessing prediction errors of generalized tree biomass and volume equations for the boreal forest region of west-central Canada. Can. J. For. Res. 38: 878-889. doi: $10.1139 / \mathrm{x} 07-212$.

Cheney, N., Gould, J., and Catchpole, W. 1998: Prediction of fire spread in grassland. Int. J. Wildland Fire 8: 1-13. doi:10.1071/WF9980001

Connolly, B.J., and Grigal, D.F. 1983. Biomass estimation equations for wetland tall shrubs. Minnesota Forestry Research Notes No. 1866. St. Paul, Minnesota, USA.

Crow, T.R., and Schlaegel, B.E. 1988. A guide to using regression equations for estimating tree biomass. North. J. Appl. For. 5: 15-22.

Cruz, M.G., Gould, J.S., Kidnie, S., Bessell, R., Nichols, D., and Slijepcevic, A. 2015. Effects of curing on grassfires: II. Effect of grass senescence on the rate of fire spread. Int. J. Wildland Fire 24: 838848. doi: 10.1071/WF14146.

Flannigan, M.D., Campbell, I., Wotton, B.M., Carcaillet, C., Richard, P., and Bergeron, Y. 2001. Future fire in Canada's boreal forest: Paleoecology results, and general circulation model - regional climate model simulations. Can. J. For. Res. 31: 854-864. doi: 10.1139/x01-010.

Flannigan, M.D., Logan, K., Amiro, B., Skinner, W., and Stocks, B. 2005. Future area burned in Canada. Clim. Change 72: 1-16. doi: 10.1007/s10584-005-5935-y. 
Flannigan, M.D., Stocks, B.J., Turetsky, M.R., and Wotton, B.M. 2009. Impacts of climate change on fire activity and fire management in the circumboreal forest. Glob. Chang. Biol. 15: 549-560. doi: 10.1111/j.1365-2486.2008.01660.x.

Forestry Canada Fire Danger Group. 1992. Development and structure of the Canadian Forest Fire Behaviour Prediction System. For. Can. Inf. Rep. ST-X-3. Ottawa, Ontario, Canada.

Frandsen, W.H. 1997. Ignition probability of organic soils. Can. J. For. Res. 27: 1471-1477. doi: 10.1139/x97-106.

Gould, J.S., McCaw, W.L., Cheney, N.P., Ellis, P.F., Knight, I.K., and Sullivan, A.L. 2007. Project Vesta - fire in dry eucalypt forest: fuel structure, fuel dynamics and fire behavior. Ensis-CSIRO, ACT and Department of Environment and Conservation, Perth, WA.

Harden, J.W., Trumbore, S.E., Stocks, B.J., Hirsch, A., Gowers, S.T., O’Neill, K.P., and Kasischke, E.S. 2000. The role of fire in the boreal carbon budget. Global Change Biol. 6: 174-184. doi: 10.1046/j.1365-2486.2000.06019.x

Hely, C., Bergeron, Y., Flannigan, M. 2000a. Coarse woody debris in the southeastern Canadian boreal forest: composition and load variations in relation to stand replacement. Can. J. For. Res. 30: 674687. doi: $10.1139 / \times 99-256$. 
Hely, C., Bergeron, Y., and Flannigan, M.D. 2000b. Effects of stand composition on fire hazard in mixed-wood Canadian boreal forest. J. Veg. Sci. 11: 813-824. doi: 10.2307/3236551.

Hines, F., Tolhurst, K.G., Wilson, A.A.G., and McCarthy, G.J. 2010. Overall Fuel Hazard Assessment Guide, $4^{\text {th }}$ Edition. Report 82 , Fire Management Branch, Department of Sustainability and Environment. Melbourne, Victoria, Australia.

Huang, X., Rein, G., and Chen, H. 2015. Computational smoldering combustion: predicting the roles of moisture and inert content in peat wildfires. Proceedings of the Combustion Institute 35: 26732681. doi: 10.1016/j.proci.2014.05.048.

Johnson, E.A. 1992. Fire and vegetation dynamics. Cambridge University Press: Cambridge, UK.

Johnston, D.C., Turetsky, M.R., Benscoter, B.W., and Wotton, B.M. 2015. Fuel load, structure and fire behaviour in forested boreal bogs. Can. J. For. Res. 45: 888-899. doi: 10.1139/cjfr-2014-0334.

Johnston, F.H., Henderson, S.B., Chen, Y., Randerson, J.T., Marlier, M., DeFries, R.S., Kinney, P., Bowman, D.M. and Brauer, M. 2012. Estimated global mortality attributable to smoke from landscape fires. Environmental health perspectives 120(5): 695-701. doi: 10.1289/ehp.1104422.

Keane, R.E. 2015. Wildland fuel fundamentals and applications. Springer: New York, USA. doi: 10.1007/978-3-319-09015-3. 
Kidnie, S., and Wotton, B.M. 2015. Characterization of the fuel and fire environment in southern Ontario's tallgrass prairie. Int. J. Wildland Fire 24: 1118-1128. doi: 10.1071/WF14214.

Kiil, A. 1968. Weight of the fuel complex in 70-year-old Lodgepoile pine stands of different densities. Canadian Department of Forestry and Rural Development. Departmental Publication No. 1228.

Lambert, M.C., Ung, C.H., and Raulier, F. 2005. Canadian national tree aboveground biomass equations. Can. J. For. Res. 35: 1996-2018. doi: 10.1139/X05-112.

Legendre, P., and Gallagher, E.D. 2001. Ecologically meaningful transformations for ordination of species data. Oecologia 129: 271-280. doi: 10.1007/s004420100716.

Loisel, J., Gallego-Sala, A.V., and Yu, Z. 2012. Global-scale patterns of peatland Sphagnum growth driven by photosynthetically active radiation and growing season length. Biogeosciences Discussions 9: 2169-2196. doi: 10.5194/bg-9-2737-2012

McRae, D.J., Alexander, M.E., and Stocks, B.J. 1979. Measurement and description of fuels and fire behaviour on prescribed burns: a handbook. Can. For. Serv. Rep. 200-X-287.

Miller, C.A., Benscoter, B.W., and Turetsky, M.R. 2015. The effect of long-term drying associated with experimental drainage and road construction on vegetation composition and productivity in boreal fens. Wetlands Ecol. Manage. 23: 845-854. doi: 10.1007/s11273-015-9423-5. 
Natural Regions Committee. 2006. Natural regions and subregions of Alberta. Compiled by D.J. Downing and W.W. Pettapiece. Government of Alberta. Publication No. T/852.

Nalder, I.A., Wein, R.W., Alexander, M.E. and De Groot, W.J., 2000. Physical properties of dead and downed round-wood fuels in the boreal forests of western and northern Canada. Int. J. Wildland Fire 9(2): 85-99. doi:10.1071/WF00008

Pastor, J., Aber, J.D., and Melillo, J.M. 1984. Biomass prediction using generalized allometric regressions for some Northeast tree species. For. Ecol. Manage. 7: 265-274. doi: 10.1016/03781127(84)90003-3.

Rappold, A.G., Stone, S.L., Cascio, W.E., Neas, L.M., Kilaru, V.J., Carraway, M.S., Szykman, J.J., Ising, A., Cleve, W.E., Meredith, J.T., Vaughan-Batten, H., Deyneka, L., and Devlin, R.B. 2011. Peat bog wildfire smoke exposure in rural North Carolina is associated with cardiopulmonary emergency department visits assessed through syndromic surveillance. Environmental health perspectives 119(10):1415-1420. doi: 10.1289/ehp.1003206.

Rein, G. 2013. Smouldering fires and natural fuels. In Fire phenomena and the earth system: an interdisciplinary guide to fire science. Edited by C.M. Belcher. John Wiley \& Sons, Oxford. doi: 10.1002/9781118529539.ch2

Rein, G., Cleaver, N., Ashton, C., Pironi, P., and Torero, J.L. 2008. The severity of smouldering peat fires and damage to the forest soil. Catena 74: 304-309. 
Stocks, B.J. 1987. Fire behavior in immature jack pine. Can. J. For. Res. 17: 80-86. doi: 10.1139/x87014.

Stocks, B.J. 1989. Fire behavior in mature jack pine. Can. J. For. Res. 19: 783-790. doi: 10.1139/x89119.

Stocks, B.J., Foseberg, M.A., Lynham, T.J., Mearns, L., Wotton, B.M., Yang, Q., Jin, J-Z., Lawrence, K., Hartley, G.R., Mason, J.A., and McKenney, D.W. 1998. Climate change and forest fire potential in Russian and Canadian boreal forests. Clim. Change 38: 1-13. doi: 10.1023/A:1005306001055.

Stocks, B.J., Alexander, M.E., Wotton, B.M., Stefner, C.N., Flannigan, M.D., Taylor, S.W., Lavoie, N., Mason, J.A., Hartley, G.R., Maffey, M.E., Dalrymple, G.N., Blake, T.W., Cruz, M.G., and Lanoville, R.A. 2004. Crown fire behaviour in a northern jack pine-black spruce forest. Can. J. For. Res. 34: 1548-1560. doi: 10.1139/X04-054

Szumigalski, A., and Bayley, S. 1996. Net above-ground primary production along a bog-rich fen gradient in central Alberta, Canada. Wetlands 16: 467-476. doi: 10.1007/BF03161336.

Tarnocai, C. 2009. The impact of climate change on Canadian peatlands. Can. Water Res. J. 34: 453466. doi: 10.4296/cwrj3404453. 
Ter-Mikaelian, M.T., and Korzukhin, M.D. 1997. Biomass equation for sixty-five North American tree species. For. Ecol. Manage. 97: 1-24. doi:10.1016/S0378- 1127(97)00019-4.

Ter-Mikaelian, M.T., Colombo, S.J., and Chen, J. 2008. Amount of downed woody debris and its prediction using stand characteristics in boreal and mixedwood forests of Ontario, Canada. Can. J. For. Res. 38: 2189-2197. doi: doi:10.1139/ X08-067.

Thompson, D.K., Wotton, B.M., and Waddington, J.M. 2015. Estimating the heat transfer to an organic soil surface during crown fire. Int. J. Wildland Fire 24: 120-129. doi: 10.1071/WF12121

Turetsky, M.R., Weider, K., Halsey, L., and Vitt, D. 2002. Current disturbance and the diminishing peatland carbon sink. Geophys. Res. Lett. 29: 1-4. doi:10.1029/2001GL014000.

Turetsky, M.R., Amiro, B., and Bhatti, J. 2004. Peatland burning and its relationship to fire weather in western Canada. Global Biogeochem. Cycles 18: GB4014.

Turetsky, M.R., Kane, E.S., Harden, J.W., Ottmar, R.D., Manies, K.L., Hoy, E., Kasischke, E.S. 2011. Recent acceleration of biomass burning and carbon losses in Alaskan forests and peatlands. Nat. Geosci. 4: 27-31. doi: doi:10.1038/ ngeo1027.

Turetsky, M.R., Benscoter, B., Page, S., Rein, G., van der Werf, G.R., and Watts, A. 2015. Global vulnerability of peatlands to fire and carbon loss. Nat. Geosci. 8: 11-14. doi: 10.1038/ngeo2325. 
Van Wagner, C.E. 1968. The line intersect method in forest fuel sampling. For. Sci. 14: 20-26.

Van Wagner, C.E. 1977. Conditions for the start and spread of crown fire. Can. J. For. Res. 7: 23-34. doi:10.1139/x77-004.

Van Wagner, C.E. 1982. Practical aspects of the line intersect method. Can. For. Serv. Inf. Rep. PI-X12.

Van Wagner, C.E. 1987. Development and structure of the Canadian Forest Fire Weather Index System. Canadian Forest Service. For. Techn. Rep. 35. Ottawa, Canada.

Vitt, D. H. 2000a. Peatlands: Ecosystems dominated by bryophytes. Bryophyte Biology. Edited by Shaw, A. J. and Goffinet, B. Cambridge University Press: Cambridge, England. pp 312-343.

Vitt, D. H., Halsey, A., Bauer, I.E., and Campbell, C. 2000b. Spatial and temporal trends of carbon sequestration in peatlands of continental western Canada through the Holocene. Can. J. Earth Sci. 37: 683-693. doi:10.1139/e99-097.

Waddington, J.M., Thompson, D.K., Wotton, M., Quinton, W.L., Flannigan, M.D., Benscoter, B.W., Baisley, S.A., and Turetsky, M.R. 2012. Examining the utility of the Canadian Forest Fire Weather Index System in boreal peatlands. Can. J. For. Res. 42: 47-58. doi:10.1139/x11-162. 
Wieder, K., Scott, K., Kamminga, K., Vile, M., Vitt, D., Bone, T., Xu, B., Benscoter, B., and Bhatti, J. 2009. Postfire carbon balance in boreal bogs of Alberta, Canada. Global Change Biology 15: 6381. doi:10.1111/j.1365-2486.2008. 01756.x.

Wotton, B.M. 2009. Interpreting and using outputs from the Canadian Forest Fire Danger Rating System in research applications. Environ. Ecol. Stat. 16: 107-131. doi: 10.1007/s10651-007-0084-2.

Wotton, B.M., and Flannigan, M.D. 1993. Length of the fire season in a changing climate. For. Chron. 69: 187-192. doi: 10.5558/tfc69187-2.

Wotton, B.M., Nock, C.A., and Flannigan, M.D. 2010. Forest fire occurrence and climate change in Canada. Int. J. Wildland Fire 19: 253-271. doi: 10.1071/WF09002.

Zoltai, S.C., Morissey, L.A., Livingston, G.P. and de Groot, W.J. 1998. Effects of fires on carbon cycling in North American boreal peatlands. Environ. Rev. 6: 13-24. doi: 10.1139/a98-0 


\section{Figure Captions}

Figure 1. Map of study region in northern Alberta, Canada. Circles indicate Open sites, triangles indicate Shrub sites, and stars indicate Treed sites. Note that the dark grey areas on the provincial map of Alberta show the Central Mixedwood subregion of the Boreal.

Figure 2. Photographs of three fen fuel types: (a) Open, (b) Shrub, (c) Treed.

Figure 3. Basal diameter frequency distribution for the Treed and Shrub sites.

Figure 4. Principal Components Analysis for fuel loads across sites.

Figure 5. Comparison of biomass and fuel loading relationships for larch and black spruce. Black lines show peatland-based allometric equations; grey lines show upland-based allometric equations; black dots are observations of destructively sampled larch trees obtained for this study. ${ }^{\text {a }}$ Schiks et al. (current study); ${ }^{\mathrm{b}}$ Johnston et al. (2015); ${ }^{\mathrm{c}}$ Bond-Lamberty et al. (2002); ${ }^{\mathrm{d}}$ Case and Hall (2008); ${ }^{\mathrm{e}}$ Lambert et al. (2005). 
Table 1. Location and general characteristics of the sites included in this study.

\begin{tabular}{llllllll}
\hline Date & $\begin{array}{l}\text { Fen } \\
\text { Type }\end{array}$ & $\begin{array}{l}\text { Site } \\
\text { Name }\end{array}$ & Age* $\begin{array}{l}\text { Latitude } \\
\left({ }^{\circ} \text { North }\right)\end{array}$ & $\begin{array}{l}\text { Longitude } \\
\left({ }^{\circ} \text { West }\right)\end{array}$ & $\begin{array}{l}\text { Elevation } \\
(\mathrm{m})\end{array}$ & $\begin{array}{l}\text { Mean Peat } \\
\text { Depth }(\mathrm{cm})\end{array}$ \\
\hline July 7, 2012 & Open & O1 & NA & 55.83524 & 115.09275 & 650 & 382 \\
July 30, 2012 & Open & O2 & NA & 55.83256 & 115.11713 & 652 & 140 \\
August 1, 2012 & Open & O3 & NA & 55.84455 & 115.06783 & 649 & 305 \\
July 3, 2012 & Shrub & S1 & 30 & 55.08831 & 113.28215 & 671 & 108 \\
July 31, 2012 & Shrub & S2 & 21 & 55.83385 & 115.08279 & 654 & 186 \\
August 2, 2012 & Shrub & S3 & 20 & 55.82533 & 115.15935 & 655 & 153 \\
July 6, 2012 & Treed & T1 & 54 & 55.82959 & 115.09089 & 656 & 197 \\
July 15, 2012 & Treed & T2 & 44 & 55.216381 & 113.17079 & 504 & 100 \\
June 29, 2012 & Treed & T3 & 46 & 55.08357 & 113.11523 & 652 & 222 \\
July 16, 2012 & Treed & T4 & NA & 55.76789 & 113.42047 & 595 & 83 \\
July 27, 2012 & Treed & T5 & 60 & 55.79689 & 113.38596 & 564 & 122 \\
\hline
\end{tabular}

*Age is the estimated time since last disturbance from fire when this could be determined via tree cores. 
Table 2. Mean and standard deviation of fuel load $\left(\mathrm{kg} / \mathrm{m}^{2}\right)$ components by fuel type.

\begin{tabular}{|c|c|c|c|c|c|c|}
\hline & \multicolumn{2}{|c|}{ Open } & \multicolumn{2}{|c|}{ Shrub } & \multicolumn{2}{|c|}{ Treed } \\
\hline & mean & $(\mathrm{SD})$ & mean & $(\mathrm{SD})$ & mean & $(\mathrm{SD})$ \\
\hline \multicolumn{7}{|l|}{ Surface fuels } \\
\hline Graminoid & 0.033 & $(0.023)$ & 0.033 & $(0.009)$ & 0.032 & $(0.029)$ \\
\hline Herbaceous & $0.005^{\mathrm{ab}}$ & $(0.006)$ & $0.007^{\mathrm{a}}$ & $(0.001)$ & $0.009^{b}$ & $(0.010)$ \\
\hline Lichen & 0.001 & $(0.001)$ & 0.000 & $(0.000)$ & 0.002 & $(0.002)$ \\
\hline Litter & 0.049 & $(0.005)$ & 0.098 & $(0.033)$ & 0.073 & $(0.009)$ \\
\hline Shrub & 0.338 & $(0.087)$ & 0.294 & $(0.247)$ & 0.191 & $(0.078)$ \\
\hline Seedlings & 0.000 & $(0.000)$ & 0.002 & $(0.004)$ & 0.003 & $(0.005)$ \\
\hline Total & 0.426 & $(0.076)$ & 0.434 & $(0.259)$ & 0.297 & $(0.075)$ \\
\hline \multicolumn{7}{|l|}{ Downed woody debris } \\
\hline$<0.5 \mathrm{~cm}$ & $0.000^{\mathrm{a}}$ & $(0.000)$ & $0.003^{b}$ & $(0.002)$ & $0.005^{\mathrm{c}}$ & $(0.000)$ \\
\hline $0.5-1.0 \mathrm{~cm}$ & $0.000^{\mathrm{a}}$ & $(0.001)$ & $0.004^{\mathrm{a}}$ & $(0.006)$ & $0.016^{\mathrm{b}}$ & $(0.001)$ \\
\hline $1.0-3.0 \mathrm{~cm}$ & $0.000^{\mathrm{a}}$ & $(0.000)$ & $0.004^{\mathrm{a}}$ & $(0.009)$ & $0.051^{\mathrm{b}}$ & $(0.000)$ \\
\hline $3.0-5.0 \mathrm{~cm}$ & $0.000^{\mathrm{a}}$ & $(0.000)$ & $0.000^{\mathrm{a}}$ & $(0.000)$ & $0.031^{\mathrm{b}}$ & $(0.000)$ \\
\hline $5.0-7.0 \mathrm{~cm}$ & $0.000^{\mathrm{a}}$ & $(0.000)$ & $0.007^{\mathrm{a}}$ & $(0.027)$ & $0.062^{b}$ & $(0.000)$ \\
\hline$>7.0 \mathrm{~cm}$ & $0.000^{\mathrm{a}}$ & $(0.000)$ & $0.000^{\mathrm{a}}$ & $(0.000)$ & $0.095^{b}$ & $(0.000)$ \\
\hline Total & $0.000^{\mathrm{a}}$ & $(0.001)$ & $0.018^{\mathrm{b}}$ & $(0.033)$ & $0.261^{\mathrm{c}}$ & $(0.001)$ \\
\hline \multicolumn{7}{|l|}{ Tall shrubs } \\
\hline Alder foliage & 0.000 & $(0.000)$ & 0.000 & $(0.000)$ & 0.001 & $(0.001)$ \\
\hline Alder branch & 0.000 & $(0.000)$ & 0.000 & $(0.000)$ & 0.016 & $(0.027)$ \\
\hline Bog birch foliage & 0.000 & $(0.000)$ & 0.014 & $(0.014)$ & 0.001 & $(0.002)$ \\
\hline Bog birch branch & 0.002 & $(0.003)$ & 0.148 & $(0.163)$ & 0.030 & $(0.048)$ \\
\hline Willow foliage & $0.000^{\mathrm{a}}$ & $(0.000)$ & $0.004^{\mathrm{ab}}$ & $(0.003)$ & $0.007^{\mathrm{b}}$ & $(0.009)$ \\
\hline Willow branch & $0.000^{\mathrm{a}}$ & $(0.000)$ & $0.017^{\mathrm{ab}}$ & $(0.015)$ & $0.054^{\mathrm{b}}$ & $(0.064)$ \\
\hline Total & $0.002^{\mathrm{a}}$ & $(0.003)$ & $0.183^{\mathrm{b}}$ & $(0.186)$ & $0.110^{\mathrm{ab}}$ & $(0.105)$ \\
\hline
\end{tabular}

Note: Superscript labels $a, b$, and c indicate significant differences $(\alpha=0.05)$ in mean values across the fen fuel type classifications for a particular fuel element. 
Table 3. Mean and standard deviation of stand and aerial fuel characteristics by fuel type.

\begin{tabular}{|c|c|c|c|c|}
\hline & \multicolumn{2}{|c|}{ Shrub } & \multicolumn{2}{|c|}{ Treed } \\
\hline & mean & $(\mathrm{SD})$ & mean & $(\mathrm{SD})$ \\
\hline \multicolumn{5}{|l|}{ Black spruce } \\
\hline Basal diameter $(\mathrm{cm})$ & $1.9^{\mathrm{a}}$ & $(0.0)$ & $4.0^{b}$ & $(0.7)$ \\
\hline Height $(\mathrm{m})$ & $1.1^{\mathrm{a}}$ & $(0.1)$ & $3.0^{\mathrm{b}}$ & $(0.6)$ \\
\hline Density (stems/ha) & $250^{\mathrm{a}}$ & $(295)$ & $4670^{\mathrm{b}}$ & $(2391)$ \\
\hline Foliage fuel load $\left(\mathrm{kg} / \mathrm{m}^{2}\right)$ & $0.003^{\mathrm{a}}$ & $(0.003)$ & $0.138^{\mathrm{b}}$ & $(0.084)$ \\
\hline Branch fuel load $\left(\mathrm{kg} / \mathrm{m}^{2}\right)$ & $0.002^{\mathrm{a}}$ & $(0.002)$ & $0.168^{\mathrm{b}}$ & $(0.104)$ \\
\hline \multicolumn{5}{|l|}{ Larch } \\
\hline Basal diameter $(\mathrm{cm})$ & $3.3^{\mathrm{a}}$ & $(0.8)$ & $3.4^{\mathrm{b}}$ & $(0.5)$ \\
\hline Height (m) & $2.3^{\mathrm{a}}$ & $(0.3)$ & $3.2^{\mathrm{b}}$ & $(0.4)$ \\
\hline Density (stems/ha) & $1275^{\mathrm{a}}$ & $(1474)$ & $4690^{b}$ & (1504) \\
\hline Foliage fuel load $\left(\mathrm{kg} / \mathrm{m}^{2}\right)$ & $0.017^{\mathrm{a}}$ & $(0.019)$ & $0.063^{b}$ & $(0.044)$ \\
\hline Branch fuel load $\left(\mathrm{kg} / \mathrm{m}^{2}\right)$ & $0.040^{\mathrm{a}}$ & $(0.045)$ & $0.185^{b}$ & $(0.126)$ \\
\hline \multicolumn{5}{|l|}{ Total } \\
\hline Canopy fuel load $\left(\mathrm{kg} / \mathrm{m}^{2}\right)$ & $0.062^{\mathrm{a}}$ & $(0.059)$ & $0.554^{\mathrm{b}}$ & $(0.192)$ \\
\hline Live crown base height (m) & $0.3^{\mathrm{a}}$ & $(0.1)$ & $0.8^{\mathrm{b}}$ & $(0.5)$ \\
\hline Crown length $(\mathrm{m})$ & $1.6^{\mathrm{a}}$ & $(0.6)$ & $2.2^{b}$ & $(1.2)$ \\
\hline Canopy bulk density $\left(\mathrm{kg} / \mathrm{m}^{3}\right)$ & $0.032^{\mathrm{a}}$ & $(0.026)$ & $0.287^{\mathrm{b}}$ & $(0.096)$ \\
\hline
\end{tabular}

Note: Superscript labels a and $b$ indicate significant differences $(\alpha=0.05)$ in mean values across the fen fuel type classifications for a particular fuel element. 
Table 4. Regression summary statistics for tree biomass relationships. Equations in the form $\ln (\mathrm{Y})=\beta_{0}+\beta_{1} * \ln ($ diameter $)$, where $\mathrm{Y}$ is fuel load $(\mathrm{kg})$, and diameter is either basal diameter $(\mathrm{cm})$ or DBH $(\mathrm{cm})$. S.E. is standard error.

\begin{tabular}{rllccccc}
\hline \multicolumn{1}{c}{ Component } & $n$ & \multicolumn{2}{c}{$\beta_{1}$ (S.E.) } & $\beta_{0}$ (S.E.) & $\mathrm{r}^{2}$ & $\mathrm{p}$-value \\
\hline Basal diameter models & & & & & & & \\
Total Biomass & 47 & 2.517 & $(0.048)$ & -3.394 & $(0.084)$ & 0.984 & $<0.0001$ \\
Stem (with bark) & 47 & 2.639 & $(0.058)$ & -4.202 & $(0.101)$ & 0.979 & $<0.0001$ \\
Branches $(<0.5 \mathrm{~cm})$ & 47 & 2.141 & $(0.049)$ & -4.247 & $(0.086)$ & 0.976 & $<0.0001$ \\
Branches $(<1.0 \mathrm{~cm})$ & 47 & 2.330 & $(0.051)$ & -4.326 & $(0.090)$ & 0.978 & $<0.0001$ \\
Total Branches & 47 & 2.388 & $(0.061)$ & -4.335 & $(0.106)$ & 0.971 & $<0.0001$ \\
Foliage & 47 & 2.185 & $(0.067)$ & -4.980 & $(0.116)$ & 0.960 & $<0.0001$ \\
DBH models $\quad$ & & & & & & & \\
Total Biomass & 39 & 1.635 & $(0.063)$ & -0.850 & $(0.098)$ & 0.947 & $<0.0001$ \\
Stem (with bark) & 39 & 1.726 & $(0.069)$ & -1.604 & $(0.108)$ & 0.943 & $<0.0001$ \\
Branches $(<0.5 \mathrm{~cm})$ & 39 & 1.355 & $(0.064)$ & -2.033 & $(0.101)$ & 0.921 & $<0.0001$ \\
Tranches $(<1.0 \mathrm{~cm})$ & 39 & 1.502 & $(0.069)$ & -1.964 & $(0.108)$ & 0.925 & $<0.0001$ \\
Total Branches & 39 & 1.545 & $(0.070)$ & -1.917 & $(0.108)$ & 0.928 & $<0.0001$ \\
& 39 & 1.357 & $(0.067)$ & -2.673 & $(0.104)$ & 0.916 & $<0.0001$
\end{tabular}

Note: Mean and range of individually harvested stems are as follows: basal diameter $=6.3 \mathrm{~cm}(1.0-14.7) ; \mathrm{DBH}=4.8 \mathrm{~cm}(0.3-11.5)$; Height $=3.9$ $\mathrm{m}(0.65-8.5)$; Total Biomass $=6.7 \mathrm{~kg}(0.04-31.7)$. 
Table 5. Byram's fireline intensity (Eqn 2) and flame length (Eqn 3) results for the fen fuel types.

\begin{tabular}{lllll}
\hline Fen type & $\begin{array}{l}\text { Rate of spread, } \mathrm{r} \\
(\mathrm{m} / \mathrm{min})\end{array}$ & Fuel consumed, $\mathrm{w}\left(\mathrm{kg} / \mathrm{m}^{2}\right)$ & Intensity, I $(\mathrm{kW} / \mathrm{m})$ & Flame length, $\mathrm{L}(\mathrm{m})$ \\
\hline Open (spring, cured) & 25 & 0.426 & 3195 & 3.2 \\
Open (summer, green) & 25 & 0.050 & 375 & 1.2 \\
Shrub & 25 & 0.624 & 4680 & 3.8 \\
Treed & 25 & 0.734 & 5505 & 4.1 \\
\hline
\end{tabular}




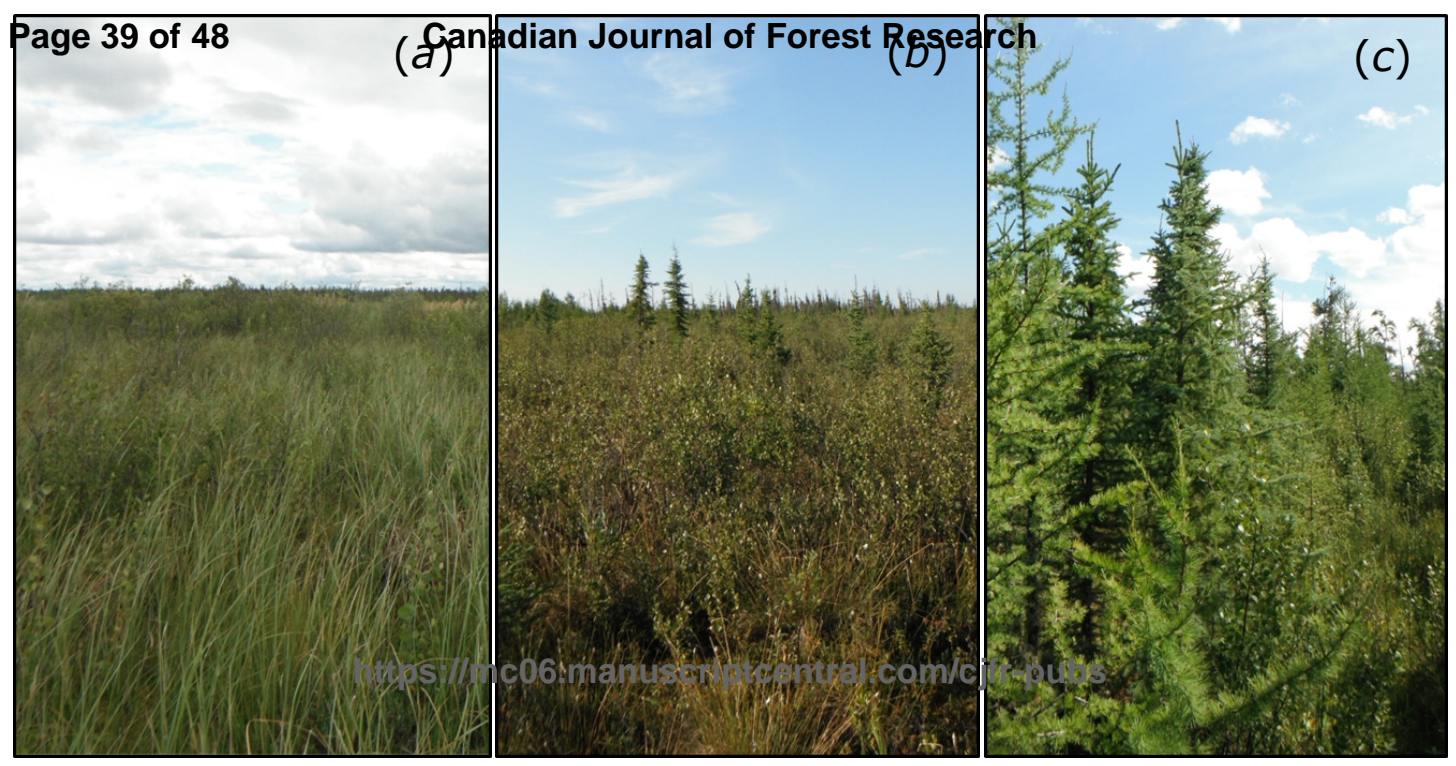


Treed fens
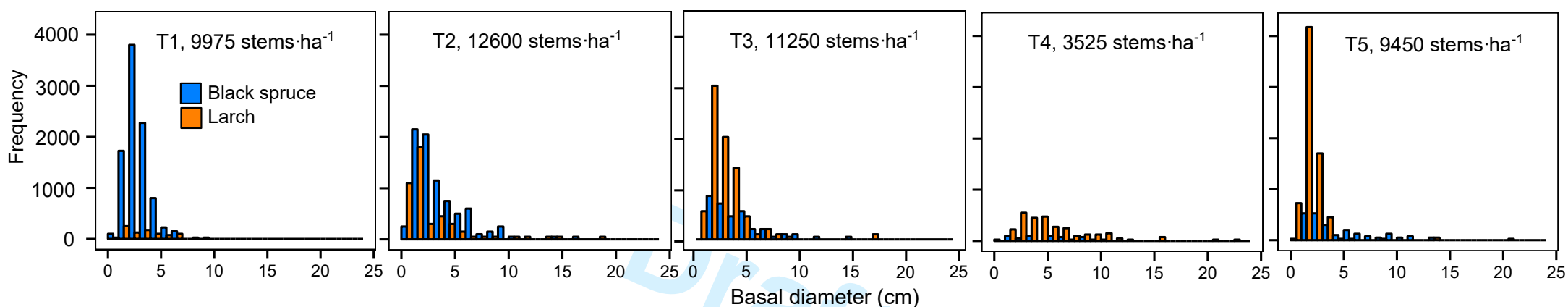

Shrub fens
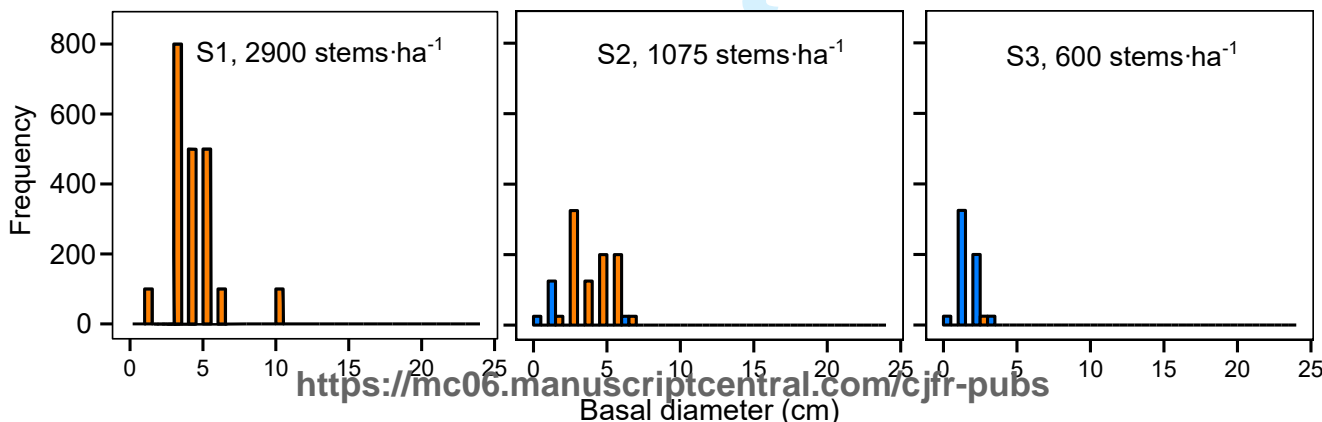

Basal diameter $(\mathrm{cm})$ 


\section{Page 41 of 48 Canadian Journal of Forest Research}

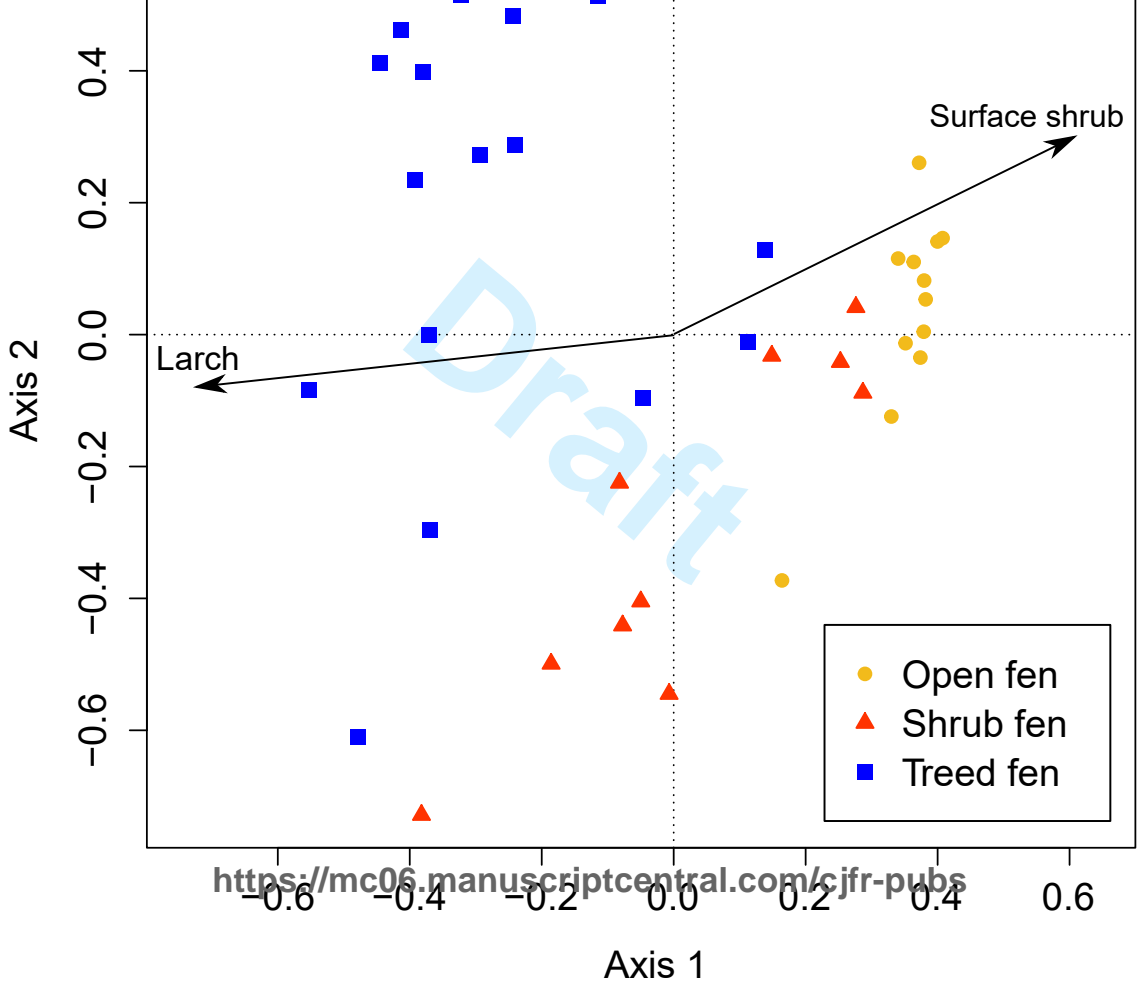



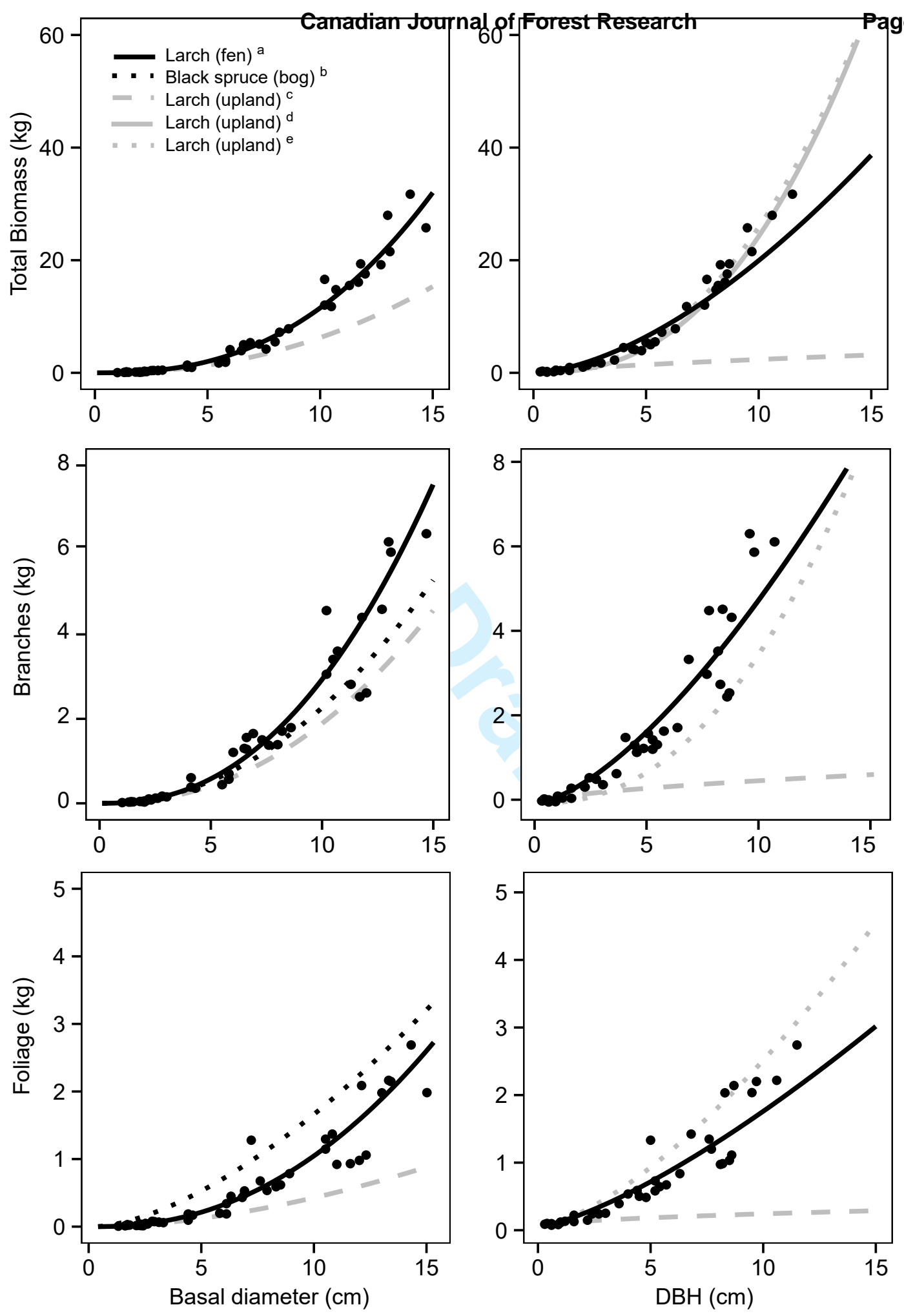

https://mc06.manuscriptcentral.com/cjfr-pubs 


\section{Appendix}

Table A-1. Mean and standard deviation of surface fuel load $\left(\mathrm{kg} / \mathrm{m}^{2}\right)$ by fuel component for each fuel type.

\begin{tabular}{|c|c|c|c|c|c|c|c|c|c|c|c|c|c|c|c|}
\hline \multirow{2}{*}{$\begin{array}{l}\text { Fen } \\
\text { Type }\end{array}$} & \multirow[b]{2}{*}{ Site } & \multicolumn{2}{|c|}{ Graminoid } & \multicolumn{2}{|c|}{ Herbaceous } & \multicolumn{2}{|c|}{ Lichen } & \multicolumn{2}{|c|}{ Litter } & \multicolumn{2}{|c|}{ Shrub } & \multicolumn{2}{|c|}{ Seedlings } & \multicolumn{2}{|c|}{ Total } \\
\hline & & Mean & SD & Mean & SD & Mean & $\mathrm{SD}$ & Mean & SD & Mean & SD & Mean & SD & Mean & SD \\
\hline \multirow[t]{4}{*}{ Open } & $\mathrm{O} 1$ & 0.008 & $(0.008)$ & 0.012 & $(0.016)$ & 0.002 & $(0.005)$ & 0.055 & $(0.037)$ & 0.411 & $(0.587)$ & 0.000 & $(0.000)$ & 0.488 & $(0.618)$ \\
\hline & $\mathrm{O} 2$ & 0.052 & $(0.042)$ & 0.001 & $(0.002)$ & 0.000 & $(0.000)$ & 0.046 & $(0.040)$ & 0.242 & $(0.352)$ & 0.000 & $(0.000)$ & 0.341 & $(0.358)$ \\
\hline & $\mathrm{O} 3$ & 0.040 & $(0.031)$ & 0.001 & $(0.001)$ & 0.002 & $(0.007)$ & 0.046 & $(0.044)$ & 0.360 & $(0.578)$ & 0.000 & $(0.000)$ & 0.450 & $(0.636)$ \\
\hline & All & 0.033 & $(0.023)$ & $0.005^{\mathrm{ab}}$ & $(0.006)$ & 0.001 & $(0.001)$ & 0.049 & $(0.005)$ & 0.338 & $(0.087)$ & 0.000 & $(0.000)$ & 0.426 & $(0.076)$ \\
\hline \multirow[t]{4}{*}{ Shrub } & $\mathrm{S} 1$ & 0.038 & $(0.040)$ & 0.007 & $(0.007)$ & 0.000 & $(0.000)$ & 0.061 & $(0.046)$ & 0.093 & $(0.101)$ & 0.000 & $(0.000)$ & 0.196 & $(0.140)$ \\
\hline & $\mathrm{S} 2$ & 0.038 & $(0.029)$ & 0.005 & $(0.007)$ & 0.000 & $(0.000)$ & 0.125 & $(0.062)$ & 0.220 & $(0.342)$ & 0.007 & $(0.024)$ & 0.396 & $(0.333)$ \\
\hline & $\mathrm{S} 3$ & 0.023 & $(0.017)$ & 0.008 & $(0.014)$ & 0.000 & $(0.000)$ & 0.109 & $(0.109)$ & 0.569 & $(0.470)$ & 0.000 & $(0.000)$ & 0.710 & $(0.426)$ \\
\hline & All & 0.033 & (0.009) & $0.007^{\mathrm{a}}$ & (0.001) & 0.000 & $(0.000)$ & 0.098 & (0.033) & 0.294 & $(0.247)$ & 0.002 & $(0.004)$ & 0.434 & $(0.259)$ \\
\hline \multirow[t]{6}{*}{ Treed } & $\mathrm{T} 1$ & 0.029 & $(0.031)$ & 0.002 & $(0.004)$ & 0.003 & $(0.004)$ & 0.078 & $(0.049)$ & 0.294 & $(0.322)$ & 0.000 & $(0.000)$ & 0.406 & $(0.334)$ \\
\hline & $\mathrm{T} 2$ & 0.005 & $(0.007)$ & 0.003 & $(0.004)$ & 0.004 & $(0.012)$ & 0.064 & $(0.046)$ & 0.155 & $(0.120)$ & 0.000 & $(0.000)$ & 0.232 & $(0.143)$ \\
\hline & T3 & 0.010 & $(0.009)$ & 0.002 & $(0.003)$ & 0.000 & $(0.000)$ & 0.078 & $(0.058)$ & 0.211 & $(0.091)$ & 0.000 & $(0.000)$ & 0.293 & (0.109) \\
\hline & $\mathrm{T} 4$ & 0.079 & $(0.055)$ & 0.023 & $(0.021)$ & 0.000 & $(0.001)$ & 0.083 & $(0.081)$ & 0.084 & $(0.153)$ & 0.012 & $(0.039)$ & 0.226 & $(0.219)$ \\
\hline & $\mathrm{T} 5$ & 0.038 & $(0.046)$ & 0.015 & $(0.015)$ & 0.001 & $(0.001)$ & 0.063 & $(0.055)$ & 0.212 & $(0.169)$ & 0.001 & $(0.002)$ & 0.330 & $(0.205)$ \\
\hline & All & 0.032 & $(0.029)$ & $0.009^{b}$ & $(0.010)$ & 0.002 & $(0.002)$ & 0.073 & $(0.009)$ & 0.191 & $(0.078)$ & 0.003 & $(0.005)$ & 0.297 & $(0.075)$ \\
\hline
\end{tabular}

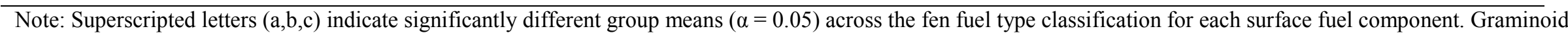
includes grasses, cotton grass and horsetail. Shrub includes bog birch and willow $(<0.5 \mathrm{~m}$ tall). Seedlings include larch and spruce $(<0.5 \mathrm{~m}$ tall). 
Table A-2. Mean and standard deviation of down woody debris $\left(\mathrm{kg} / \mathrm{m}^{2}\right)$ by size class for each fuel type.

\begin{tabular}{|c|c|c|c|c|c|c|c|c|c|c|c|c|c|c|c|}
\hline \multirow[b]{2}{*}{ Type } & \multirow[b]{2}{*}{ Site } & \multicolumn{2}{|c|}{$<0.5 \mathrm{~cm}$} & \multicolumn{2}{|c|}{$0.5-1.0 \mathrm{~cm}$} & \multicolumn{2}{|c|}{$1.0-3.0 \mathrm{~cm}$} & \multicolumn{2}{|c|}{$3.0-5.0 \mathrm{~cm}$} & \multicolumn{2}{|c|}{$5.0-7.0 \mathrm{~cm}$} & \multicolumn{2}{|c|}{$>7 \mathrm{~cm}$} & \multicolumn{2}{|c|}{ Total } \\
\hline & & Mean & SD & Mean & SD & Mean & SD & Mean & SD & Mean & SD & Mean & SD & Mean & SD \\
\hline \multirow[t]{4}{*}{ Open } & O1 & 0.000 & $(0.000)$ & 0.000 & $(0.000)$ & 0.000 & $(0.000)$ & 0.000 & $(0.000)$ & 0.000 & $(0.000)$ & 0.000 & $(0.000)$ & 0.000 & $(0.000)$ \\
\hline & $\mathrm{O} 2$ & 0.000 & $(0.000)$ & 0.001 & $(0.001)$ & 0.000 & $(0.000)$ & 0.000 & $(0.000)$ & 0.000 & $(0.000)$ & 0.000 & $(0.000)$ & 0.001 & $(0.001)$ \\
\hline & $\mathrm{O} 3$ & 0.000 & $(0.000)$ & 0.000 & $(0.000)$ & 0.000 & $(0.000)$ & 0.000 & $(0.000)$ & 0.000 & $(0.000)$ & 0.000 & $(0.000)$ & 0.000 & $(0.000)$ \\
\hline & All & $0.000^{\mathrm{a}}$ & $(0.000)$ & $0.000^{\mathrm{a}}$ & $(0.001)$ & $0.000^{\mathrm{a}}$ & $(0.000)$ & $0.000^{\mathrm{a}}$ & $(0.000)$ & $0.000^{\mathrm{a}}$ & $(0.000)$ & $0.000^{\mathrm{a}}$ & $(0.000)$ & $0.000^{\mathrm{a}}$ & $(0.001)$ \\
\hline \multirow[t]{4}{*}{ Shrub } & $\mathrm{S} 1$ & 0.004 & $(0.001)$ & 0.012 & $(0.005)$ & 0.005 & $(0.011)$ & 0.000 & $(0.000)$ & 0.000 & $(0.000)$ & 0.000 & $(0.000)$ & 0.021 & $(0.015)$ \\
\hline & $\mathrm{S} 2$ & 0.001 & $(0.001)$ & 0.000 & $(0.000)$ & 0.005 & $(0.011)$ & 0.000 & $(0.000)$ & 0.021 & $(0.046)$ & 0.000 & $(0.000)$ & 0.027 & $(0.058)$ \\
\hline & $\mathrm{S} 3$ & 0.003 & $(0.001)$ & 0.001 & $(0.001)$ & 0.003 & $(0.006)$ & 0.000 & $(0.000)$ & 0.000 & $(0.000)$ & 0.000 & $(0.000)$ & 0.006 & $(0.005)$ \\
\hline & All & $\mathbf{0 . 0 0 3}^{\mathrm{b}}$ & $(0.002)$ & $0.004^{\mathrm{a}}$ & $(0.006)$ & $0.004^{\mathrm{a}}$ & (0.009) & $0.000^{\mathrm{a}}$ & $(0.000)$ & $0.007^{\mathrm{a}}$ & (0.027) & $0.000^{\mathrm{a}}$ & $(0.000)$ & $0.018^{b}$ & $(0.033)$ \\
\hline \multirow[t]{6}{*}{ Treed } & $\mathrm{T} 1$ & 0.006 & $(0.004)$ & 0.015 & $(0.009)$ & 0.057 & $(0.034)$ & 0.062 & $(0.113)$ & 0.041 & $(0.093)$ & 0.074 & $(0.166)$ & 0.256 & $(0.395)$ \\
\hline & $\mathrm{T} 2$ & 0.008 & $(0.004)$ & 0.033 & $(0.016)$ & 0.141 & (0.089) & 0.042 & $(0.044)$ & 0.062 & $(0.057)$ & 0.059 & $(0.132)$ & 0.345 & $(0.258)$ \\
\hline & $\mathrm{T} 3$ & 0.004 & $(0.001)$ & 0.007 & $(0.008)$ & 0.021 & $(0.011)$ & 0.010 & $(0.023)$ & 0.062 & $(0.093)$ & 0.164 & $(0.169)$ & 0.268 & $(0.257)$ \\
\hline & $\mathrm{T} 4$ & 0.003 & $(0.001)$ & 0.008 & $(0.007)$ & 0.008 & $(0.007)$ & 0.000 & $(0.000)$ & 0.021 & $(0.046)$ & 0.000 & $(0.000)$ & 0.039 & $(0.047)$ \\
\hline & T5 & 0.006 & $(0.006)$ & 0.015 & $(0.018)$ & 0.028 & $(0.038)$ & 0.042 & $(0.044)$ & 0.124 & $(0.113)$ & 0.180 & $(0.165)$ & 0.395 & $(0.141)$ \\
\hline & All & $0.005^{c}$ & $(0.000)$ & $0.016^{b}$ & $(0.001)$ & $0.051^{b}$ & $(0.000)$ & $0.031^{b}$ & $(0.000)$ & $0.062^{b}$ & $(0.000)$ & $0.095^{b}$ & $(0.000)$ & $0.261^{c}$ & (0.001) \\
\hline
\end{tabular}

Note: Superscripted letters $(a, b, c)$ indicate significantly different group means $(\alpha=0.05)$ across the fen fuel type classifications for each fuel size class component. 
Table A- 3. Mean and standard deviation of shrub fuel load $\left(\mathrm{kg} / \mathrm{m}^{2}\right)$, shrub height (m) and shrub fuel bulk density ( $\left.\mathrm{kg} / \mathrm{m}^{3}\right)$ for each fuel type.

\begin{tabular}{|c|c|c|c|c|c|c|c|c|c|c|c|c|c|c|c|c|c|c|}
\hline \multirow{3}{*}{$\begin{array}{l}\text { Type } \\
\text { Open }\end{array}$} & \multirow{3}{*}{$\frac{\text { Site }}{\mathrm{O} 1}$} & \multicolumn{2}{|c|}{ Alder foliage } & \multicolumn{2}{|c|}{ Alder branch } & \multicolumn{2}{|c|}{$\begin{array}{l}\text { Bog birch } \\
\text { foliage }\end{array}$} & \multicolumn{2}{|c|}{$\begin{array}{c}\text { Bog birch } \\
\text { branch }\end{array}$} & \multicolumn{2}{|c|}{ Willow foliage } & \multicolumn{2}{|c|}{ Willow branch } & \multirow{2}{*}{\multicolumn{2}{|c|}{$\begin{array}{c}\text { Shrub load } \\
\left(\mathrm{kg} / \mathrm{m}^{2}\right)\end{array}$}} & \multirow{2}{*}{\multicolumn{2}{|c|}{ Height (m) }} & \multirow{2}{*}{$\begin{array}{r}\text { Bulk de } \\
(\mathrm{kg} / \mathrm{n}\end{array}$} \\
\hline & & \multirow{2}{*}{$\begin{array}{l}\text { Mean } \\
0.000\end{array}$} & \multirow{2}{*}{$\frac{\mathrm{SD}}{(0.000)}$} & \multirow{2}{*}{$\begin{array}{l}\text { Mean } \\
0.000\end{array}$} & \multirow{2}{*}{$\frac{\mathrm{SD}}{(0.000)}$} & \multirow{2}{*}{$\frac{\text { Mean }}{0.000}$} & \multirow{2}{*}{$\frac{\mathrm{SD}}{(0.000)}$} & \multirow{2}{*}{$\begin{array}{l}\text { Mean } \\
0.005\end{array}$} & \multirow{2}{*}{$\frac{\mathrm{SD}}{(0.004)}$} & \multirow{2}{*}{$\frac{\text { Mean }}{0.000}$} & \multirow{2}{*}{$\frac{\mathrm{SD}}{(0.000)}$} & \multirow{2}{*}{$\frac{\text { Mean }}{0.000}$} & \multirow{2}{*}{$\frac{\mathrm{SD}}{(0.000)}$} & & & & & \\
\hline & & & & & & & & & & & & & & 0.005 & $(0.004)$ & 1.0 & $(0.0)$ & 0.005 \\
\hline & $\mathrm{O} 2$ & 0.000 & $(0.000)$ & 0.000 & $(0.000)$ & 0.000 & $(0.000)$ & 0.000 & $(0.000)$ & 0.000 & $(0.000)$ & 0.000 & $(0.000)$ & 0.000 & $(0.000)$ & NA & NA & 0.000 \\
\hline & $\mathrm{O} 3$ & 0.000 & $(0.000)$ & 0.000 & $(0.000)$ & 0.000 & $(0.000)$ & 0.000 & $(0.000)$ & 0.000 & $(0.000)$ & 0.000 & $(0.000)$ & 0.000 & $(0.000)$ & $\mathrm{NA}$ & NA & 0.000 \\
\hline & All & 0.000 & $(0.000)$ & 0.000 & $(0.000)$ & 0.000 & $(0.000)$ & 0.002 & $(0.003)$ & $0.000^{\mathrm{a}}$ & $(0.000)$ & $0.000^{\mathrm{a}}$ & $(0.000)$ & $0.002^{\mathrm{a}}$ & $(0.003)$ & $1.0^{\mathrm{a}}$ & - & $0.002^{\mathrm{a}}$ \\
\hline \multirow[t]{4}{*}{ Shrub } & S1 & 0.000 & $(0.000)$ & 0.000 & $(0.000)$ & 0.029 & $(0.008)$ & 0.333 & $(0.034)$ & 0.005 & $(0.001)$ & 0.030 & $(0.019)$ & 0.397 & $(0.022)$ & 1.2 & $(0.0)$ & 0.324 \\
\hline & S2 & 0.000 & $(0.000)$ & 0.000 & $(0.000)$ & 0.011 & $(0.003)$ & 0.085 & $(0.051)$ & 0.000 & $(0.000)$ & 0.000 & $(0.000)$ & 0.096 & $(0.054)$ & 1.1 & $(0.1)$ & 0.083 \\
\hline & $\mathrm{S} 3$ & 0.000 & $(0.000)$ & 0.000 & $(0.000)$ & 0.003 & $(0.002)$ & 0.026 & $(0.027)$ & 0.006 & $(0.003)$ & 0.023 & $(0.014)$ & 0.057 & $(0.026)$ & 1.2 & $(0.1)$ & 0.049 \\
\hline & All & 0.000 & $(0.000)$ & 0.000 & $(0.000)$ & 0.014 & $(0.014)$ & 0.148 & $(0.163)$ & $0.004^{a b}$ & $(0.003)$ & $0.017^{a b}$ & $(0.015)$ & $0.183^{b}$ & $(0.186)$ & $1.2^{\mathrm{b}}$ & $(0.0)$ & $0.152^{b}$ \\
\hline \multirow[t]{6}{*}{ Treed } & $\mathrm{T} 1$ & 0.000 & $(0.000)$ & 0.000 & $(0.000)$ & 0.002 & $(0.002)$ & 0.026 & $(0.027)$ & 0.002 & $(0.002)$ & 0.009 & $(0.010)$ & 0.039 & $(0.041)$ & 1.2 & $(0.1)$ & 0.034 \\
\hline & $\mathrm{T} 2$ & 0.000 & $(0.001)$ & 0.018 & $(0.026)$ & 0.001 & $(0.002)$ & 0.009 & $(0.012)$ & 0.022 & $(0.013)$ & 0.160 & $(0.024)$ & 0.210 & $(0.076)$ & 2.0 & $(0.4)$ & 0.113 \\
\hline & T3 & 0.000 & $(0.000)$ & 0.000 & $(0.000)$ & 0.000 & $(0.000)$ & 0.000 & $(0.000)$ & 0.000 & $(0.000)$ & 0.000 & $(0.000)$ & 0.000 & $(0.000)$ & NA & NA & 0.000 \\
\hline & $\mathrm{T} 4$ & 0.003 & $(0.005)$ & 0.063 & $(0.101)$ & 0.004 & $(0.005)$ & 0.114 & $(0.132)$ & 0.003 & $(0.004)$ & 0.047 & $(0.071)$ & 0.234 & $(0.032)$ & 2.2 & $(0.5)$ & 0.113 \\
\hline & $\mathrm{T} 5$ & 0.000 & $(0.000)$ & 0.000 & $(0.000)$ & 0.000 & $(0.001)$ & 0.003 & $(0.006)$ & 0.008 & $(0.003)$ & 0.053 & $(0.020)$ & 0.065 & $(0.020)$ & 1.7 & $(0.3)$ & 0.039 \\
\hline & All & 0.001 & $(0.001)$ & 0.016 & $(0.027)$ & 0.001 & $(0.002)$ & $\mathbf{0 . 0 3 0}$ & (0.048) & $0.007^{b}$ & $(0.009)$ & $0.054^{b}$ & $(0.064)$ & $0.110^{a b}$ & $(0.105)$ & $1.8^{\mathrm{b}}$ & (0.4) & $0.060^{\mathrm{ab}}$ \\
\hline
\end{tabular}

Note: Superscripted letters $(\mathrm{a}, \mathrm{b})$ indicate significant differences $(\alpha=0.05)$ in group means across the fen fuel type classification. 
Table A-4. Mean and standard deviation for aerial fuels in the shrub and treed fuel types.

\begin{tabular}{|c|c|c|c|c|c|c|c|c|c|c|c|c|c|c|c|c|c|}
\hline \multirow[b]{2}{*}{ Type } & \multirow[b]{2}{*}{ Site } & \multicolumn{4}{|c|}{ Black spruce load $\left(\mathrm{kg} / \mathrm{m}^{2}\right)$} & \multicolumn{4}{|c|}{ Larch load $\left(\mathrm{kg} / \mathrm{m}^{2}\right)$} & \multirow{2}{*}{\multicolumn{2}{|c|}{$\begin{array}{l}\text { Canopy fuel } \\
\text { load }\left(\mathrm{kg} / \mathrm{m}^{2}\right)\end{array}$}} & \multirow{2}{*}{\multicolumn{2}{|c|}{$\begin{array}{l}\text { Live crown } \\
\text { base height } \\
(\mathrm{m})\end{array}$}} & \multirow{2}{*}{\multicolumn{2}{|c|}{$\begin{array}{c}\text { Crown } \\
\text { length }(\mathrm{m})\end{array}$}} & \multirow{2}{*}{\multicolumn{2}{|c|}{$\begin{array}{c}\text { Canopy bulk } \\
\text { density }\left(\mathrm{kg} / \mathrm{m}^{3}\right)\end{array}$}} \\
\hline & & \multicolumn{2}{|c|}{ Foliage } & \multicolumn{2}{|c|}{ Branch } & \multicolumn{2}{|c|}{ Foliage } & \multicolumn{2}{|c|}{ Branch } & & & & & & & & \\
\hline \multirow{5}{*}{ Shrub } & & & $(0.000$ & & $(0.000$ & & $(0.003$ & & $(0.007$ & & $(0.010$ & & & & & & $(0.005$ \\
\hline & $\mathrm{S} 1$ & 0.000 & $\begin{array}{c})_{(0.004} \\
(0.004\end{array}$ & 0.000 & $\begin{array}{c})_{(0.005} \\
(0.005\end{array}$ & 0.037 & $\begin{array}{c})_{(0.012} \\
(0.01\end{array}$ & 0.089 & $\begin{array}{c})_{(0.030} \\
(0.030)\end{array}$ & 0.126 & $\begin{array}{c})_{(0.040} \\
(0.040\end{array}$ & 0.5 & $(0.2)$ & 2.0 & $(0.0)$ & 0.062 & $\begin{array}{c})_{(0.017} \\
(0.017\end{array}$ \\
\hline & $\mathrm{S} 2$ & 0.003 & $\begin{array}{c})_{(0.003} \\
(0.003\end{array}$ & 0.003 & $\begin{array}{c})_{(0.002} \\
(0.002\end{array}$ & 0.012 & $\begin{array}{c})_{(0.000} \\
(0.000\end{array}$ & 0.031 & $\begin{array}{c})_{(0.001} \\
(0.001\end{array}$ & 0.050 & $\begin{array}{c})_{(0.005} \\
(0.005\end{array}$ & 0.3 & $(0.1)$ & 1.9 & $(0.4)$ & 0.025 & $\begin{array}{c})_{(0.005} \\
(0.005\end{array}$ \\
\hline & & 0.003 & $(0.003$ & 0.002 & $(0.002$ & 0.017 & $(0.019$ & 0.040 & $(0.045$ & 0.062 & $(0.059$ & & & & & 0.032 & $(0.026$ \\
\hline & All & a & $\begin{array}{c}\text { ) } \\
(0.034\end{array}$ & a & $\begin{array}{c}\text { ) } \\
(0.016\end{array}$ & a & $\begin{array}{c}) \\
(0.020\end{array}$ & a & $\begin{array}{c}) \\
(0.049\end{array}$ & a & $\begin{array}{c}) \\
(0.046\end{array}$ & $0.3^{\mathrm{a}}$ & $(0.1)$ & $1.6^{\mathrm{a}}$ & $(0.6)$ & $\mathrm{a}$ & $\begin{array}{c}) \\
(0.092\end{array}$ \\
\hline \multirow[t]{5}{*}{ Treed } & $\mathrm{T} 1$ & 0.190 & $\begin{array}{c})_{(0.098} \\
(0.096\end{array}$ & 0.173 & $\begin{array}{c})_{(0.153} \\
(0.153\end{array}$ & 0.010 & $\begin{array}{c})_{(0.037} \\
(0.037\end{array}$ & 0.025 & $\begin{array}{c})_{(0.022} \\
(0.022\end{array}$ & 0.399 & $\begin{array}{c})_{(0.192} \\
(0.192\end{array}$ & 0.3 & $(0.2)$ & 1.4 & $(0.3)$ & 0.295 & $\begin{array}{c})_{(0.134} \\
(0.13\end{array}$ \\
\hline & $\mathrm{T} 2$ & 0.249 & $\begin{array}{c})_{(0.098} \\
(0.096\end{array}$ & 0.329 & $\begin{array}{c})_{(0.144} \\
(0.14\end{array}$ & 0.061 & $\begin{array}{c})_{(0.011} \\
(0.01\end{array}$ & 0.216 & $\begin{array}{c})_{(0.085} \\
(0.085\end{array}$ & 0.856 & $\begin{array}{c})_{(0.146} \\
(0.146\end{array}$ & 1.0 & $(0.2)$ & 2.9 & $(0.6)$ & 0.310 & $\begin{array}{c}{ }_{(0.101} \\
(0.101\end{array}$ \\
\hline & $\mathrm{T} 4$ & 0.038 & $\begin{array}{c})_{(0.048} \\
(0.04\end{array}$ & 0.041 & $\begin{array}{c})_{(0.072} \\
(0.07\end{array}$ & 0.131 & $\begin{array}{c})_{(0.019} \\
(0.019\end{array}$ & 0.358 & $\begin{array}{c})_{(0.058} \\
(0.058\end{array}$ & 0.568 & $\begin{array}{c})_{(0.150} \\
(0.150\end{array}$ & 1.6 & $(0.1)$ & 4.1 & $(0.9)$ & 0.140 & $\begin{array}{c}{ }^{\prime} \\
(0.145\end{array}$ \\
\hline & $\mathrm{T} 5$ & 0.084 & ) & 0.138 & ) & 0.043 & ) & 0.111 & ) & 0.376 & ) & 0.8 & $(0.4)$ & 1.4 & $(0.3)$ & 0.284 & ) \\
\hline & All & $\underset{b}{0.138}$ & $\begin{array}{c}(0.084 \\
)\end{array}$ & $\underset{b}{0.168}$ & $\begin{array}{c}(0.104 \\
)\end{array}$ & $\underset{b}{0.063}$ & $\begin{array}{c}(0.044 \\
)\end{array}$ & $\underset{b}{0.185}$ & $\begin{array}{c}(0.126 \\
)\end{array}$ & $\underset{b}{0.554}$ & $\begin{array}{c}(0.192 \\
)\end{array}$ & $\underset{b}{0.8}$ & $(0.5)$ & $\underset{b}{2.2}$ & (1.2) & $\underset{b}{0.287}$ & $\begin{array}{c}(0.096 \\
)\end{array}$ \\
\hline
\end{tabular}

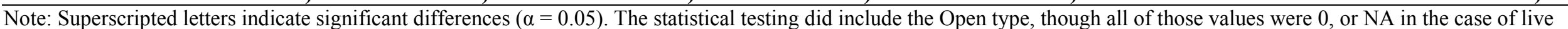
crown base height. 
Table A-5. Mean and standard deviation for stand characteristics of treed and shrub fuel types.

\begin{tabular}{|c|c|c|c|c|c|c|c|c|c|c|c|c|c|}
\hline \multirow{3}{*}{$\begin{array}{l}\text { Type } \\
\text { Shrub }\end{array}$} & \multirow{3}{*}{$\begin{array}{l}\text { Site } \\
\text { S1 }\end{array}$} & \multicolumn{6}{|c|}{ Black spruce } & \multicolumn{6}{|c|}{ Larch } \\
\hline & & \multicolumn{2}{|c|}{$\begin{array}{c}\text { Basal } \\
\text { diameter }(\mathrm{cm}) \\
\end{array}$} & \multicolumn{2}{|c|}{ Height (m) } & \multicolumn{2}{|c|}{$\begin{array}{c}\text { Density } \\
\text { (stems/ha) }\end{array}$} & \multicolumn{2}{|c|}{$\begin{array}{c}\text { Basal } \\
\text { diameter }(\mathrm{cm}) \\
\end{array}$} & \multicolumn{2}{|c|}{ Height (m) } & \multicolumn{2}{|c|}{$\begin{array}{c}\text { Density } \\
\text { (stems/ha) }\end{array}$} \\
\hline & & NA & NA & NA & NA & 0 & $(0)$ & 3.7 & $(0.5)$ & 2.5 & $(0.2)$ & 2900 & (990) \\
\hline & $\mathrm{S} 2$ & 1.9 & (1.4) & 1.1 & $(0.8)$ & 175 & $(96)$ & 3.8 & $(0.8)$ & 2.5 & $(0.3)$ & 900 & (804) \\
\hline & $\mathrm{S} 3$ & 1.9 & $(0.4)$ & 1.2 & $(0.2)$ & 575 & $(206)$ & 2.4 & - & 2.0 & - & 25 & $(50)$ \\
\hline & All & $1.9^{\mathrm{a}}$ & $(0.0)$ & $1.1^{\mathrm{a}}$ & (0.1) & $250^{\mathrm{a}}$ & (295) & $3.3^{\mathrm{a}}$ & (0.8) & $2.3^{\mathrm{a}}$ & $(0.3)$ & $1275^{\mathrm{a}}$ & (1474) \\
\hline \multirow[t]{6}{*}{ Treed } & $\mathrm{T} 1$ & 2.8 & $(0.2)$ & 1.6 & $(0.1)$ & 9125 & (2074) & 3.1 & $(0.2)$ & 2.3 & $(0.2)$ & 850 & (1634) \\
\hline & $\mathrm{T} 2$ & 3.6 & $(0.3)$ & 4.3 & (1.5) & 8100 & (6364) & 3.2 & (1.4) & 4.2 & $(0.9)$ & 4500 & (3536) \\
\hline & $\mathrm{T} 3$ & 3.6 & $(1.0)$ & 2.4 & $(0.3)$ & 3300 & (1556) & 2.6 & $(0.1)$ & 1.6 & $(0.0)$ & 7950 & (3748) \\
\hline & $\mathrm{T} 4$ & 5.4 & (1.8) & 3.3 & $(0.6)$ & 600 & $(316)$ & 5.5 & $(0.7)$ & 6.0 & $(1.0)$ & 2925 & (793) \\
\hline & $\mathrm{T} 5$ & 4.3 & $(1.2)$ & 3.5 & (1.1) & 2225 & $(950)$ & 2.4 & (0.9) & 1.9 & $(0.7)$ & 7225 & (4291) \\
\hline & All & $4.0^{b}$ & $(0.7)$ & $3.0^{b}$ & (0.6) & $4670^{b}$ & (2391) & $3.4^{\mathrm{b}}$ & $(0.5)$ & $3.2^{\mathrm{b}}$ & (0.4) & $4690^{b}$ & (1504) \\
\hline
\end{tabular}

Note: Superscripted letters (a.b) indicate significant differences $(\alpha=0.05)$ in group means across the fen fuel type classification. 